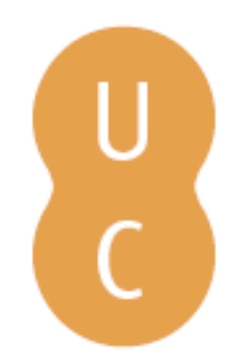

\title{
nombalina
}

\section{Politeía Tropical: a recepção dos clássicos, a tradição política no Brasil do século XIX e a tradução das categorias aristotélicas por Sỉlvestre Pinheiro Ferreira}

Autor(es): $\quad$ Augusto, Maria das Graças de Moraes

Publicado por: Imprensa da Universidade de Coimbra

URL

persistente: URI:http://hdl.handle.net/10316.2/37051

DOI: $\quad$ DOI:http://dx.doi.org/10.14195/978-989-26-1043-6_1

Accessed : $\quad$ 26-Apr-2023 12:32:31

A navegação consulta e descarregamento dos títulos inseridos nas Bibliotecas Digitais UC Digitalis, UC Pombalina e UC Impactum, pressupõem a aceitação plena e sem reservas dos Termos e Condições de Uso destas Bibliotecas Digitais, disponíveis em https://digitalis.uc.pt/pt-pt/termos.

Conforme exposto nos referidos Termos e Condições de Uso, o descarregamento de títulos de acesso restrito requer uma licença válida de autorização devendo o utilizador aceder ao(s) documento(s) a partir de um endereço de IP da instituição detentora da supramencionada licença.

Ao utilizador é apenas permitido o descarregamento para uso pessoal, pelo que o emprego do(s) título(s) descarregado(s) para outro fim, designadamente comercial, carece de autorização do respetivo autor ou editor da obra.

Na medida em que todas as obras da UC Digitalis se encontram protegidas pelo Código do Direito de Autor e Direitos Conexos e demais legislação aplicável, toda a cópia, parcial ou total, deste documento, nos casos em que é legalmente admitida, deverá conter ou fazer-se acompanhar por este aviso.

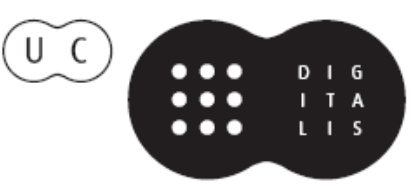


politica no Brasil do sécu

Categorias aristotélicas por Silvestre Pinheiro Ferreira - Musas errantes: tesouros da Antiguidade Clássica no labirinto da Biblioteca Nacional Brasileira - Eudoro de Sousa e a Mitologia • Câmara Cascudo em defesa de Epicuro - Medéia carioca - Ecos de Platão em Vergílio Ferreira - Imaginário clássico na poesia de António Arnaut - Motivos clássicos na poesia novilatina em Portugal: Manuel da Costa - Uma Ifigénia portuguesa: "Noite escura" de João Canijo • Uma leitura de Mau Tempo no Canal de Vitorino Nemésio $\bullet A$ phýsis grega e o Brasil: as viagens de Von Martius $\bullet$ Fantasia para dois coronéis e uma piscina. Ecos clássicos num contexto do séc. XX

\section{A RECEPÇÃO DOS CLÁSSICOS EM PORTUGAL E NO BRASIL}

Maria de Fátima Silva Maria das Graças de Moraes Augusto COORDENAÇÃo 


\section{SÉRIE MITO E (RE)ESCRITA}

ISSN: $2182-8814$

\section{PERIODICIDADE: Anual}

Apresentação: Poetas, pintores, escultores, na Antiguidade, familiarizados com mitos antigos de deuses e de homens, que cristalizavam experiências, interrogaçóes, respostas quanto à existência do homem no tempo e no mundo, em mitos se inspiraram, em contínua criação-recriaçẩo, para neles verterem a sua própria experiência temporal, com todos os desassossegos e inquietaçóes, com todo o espanto, horror ou encantamento pela excecionalidade da ação humana, que rasga ou ilumina fronteiras de finitude. Esses percursos da criação merecem, hoje, a atenção e análise dos Estudos Literários e, como não podia deixar de ser, dos Estudos Clássicos, muito peculiarmente. Importa, pois, proceder à publicação sistemática de estudos deste cariz, que se destaquem pela qualidade científica e pela originalidade, sendo dedicados, sobretudo, a autores de língua portuguesa. Assim se dá corpo à linha editorial MITO E (RE)ESCRITA.

Este livro, realizado no âmbito do Convénio de Cooperação Académica entre o CECH - Centro de Estudos Clássicos e Humanísticos da UC - e o PRAGMA - Programa de Estudos de Filosofia Antiga da UFRJ -, reúne um conjunto de estudos sobre a recepçáo de temas e modelos greco-latinos na literatura e cultura de Portugal e Brasil.

A sua originalidade resulta da participação de diferentes culturas e das especialidades académicas diversas dos investigadores que nele participam, provenientes da Literatura, da Filosofia e da História Antiga. O lapso de tempo abrangido, que vai do séc. XVI ao XX, permite uma visáo de conjunto da evoluçáo operada no perfil cultural de ambos os países e na definição de um trajeto em boa parte comum. 


\title{
Politeía Tropical: a recepção dos clássicos, a tradição política no Brasil do século XIX e a tradução das Categorias aristotélicas por Silvestre Pinheiro Ferreira
}

(Tropical Politeía: Classical reception, the political tradition in nineteenth-century Brazil and the translation of Aristotle's Categories by Silvestre Pinheiro Ferreira)

\author{
Maria das Graças de Moraes Augusto \\ Instituto de Filosofia e Ciências Sociais \\ Universidade Federal do Rio de Janeiro
}


Página deixada propositadamente em branco 
Resumo - A importância do século XIX para a história da recepção dos clássicos gregos na vida política brasileira e as traduçôes que são elaboradas ao longo desse período, além de serem um fato inequívoco, podem nos auxiliar a compreender o processo de concepção da ideia de uma "nação brasileira".

Nesse sentido, nosso objetivo aqui consiste na retomada da tradução das Categorias, de Aristóteles, feita por Silvestre Pinheiro Ferreira, e publicada no Rio de Janeiro, em 1814, pela Impressão Régia, para servir de base às suas Preleçôes Filosóficas, ministradas entre 1813-1815, no Rio de Janeiro, no contexto das obras do autor - a Gramática Filosófica e a Memória sobre um novo princípio da Teórica do Calórico-, publicadas, no jornal O Patriota, também, no Rio de Janeiro, em 1813, e nos 30 fascículos que compóem suas Preleçôes Filosóficas, buscando evidenciar que a 'lógica dos termos' aristotélica subjaz em toda a discussão silvestriana no referido período.

Palavras-Chave - Silvestre Pinheiro Ferreira. Aristóteles. Categorias. Preleçóes Filosóficas. O Patriota. Corte Portuguesa no Brasil.

Abstract - The importance of the nineteenth century to the history of the reception of Greek classics in Brazilian political life and the texts that were translated during this period, in addition to being an unequivocal fact, can help us to understand the process of the conception of the idea of a "Brazilian nation".

In this sense, our goal here is to revisit Silvestre Pinheiro Ferreira's translation of Aristotle's Categories, published in Rio de Janeiro in 1814 by the Royal Printing, to serve as a basis for his Philosophical Lectures, held between 1813 and 1815, in Rio de Janeiro, in the context of the works of the author - the Philosophical Grammar and the Memoir on a new principle of the caloric theory, published in 1813, also in Rio de Janeiro, in the newspaper The Patriot and in the 30 fascicles that form his Philosophical Lectures, seeking to highlight that the Aristotelian term logic underlies the whole Silvestrian discussion during the above mentioned period.

Keywords - Silvestre Pinheiro Ferreira. Aristotle. Categories. Philosophical Lectures. The Patriot. Portuguese Court in Brazil.

À memória de Germanus Strazzeri, com saudades das nossas tardes de trabalho na Biblioteca Nacional do Rio de Janeiro.

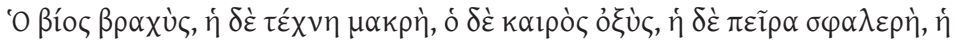

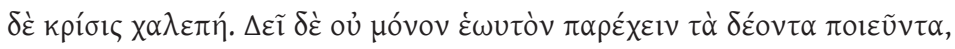

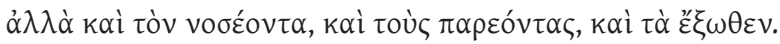

$$
\text { Hp., Aph., I, } 1 .
$$

"Os fatos são passageiros; as datas incertas; os homens mortais, - só as ideias são permanentes e eternas as categorias por que elas se exprimem."

Pedro Nava, Capitulos da História da Medicina no Brasil, 1948. 
Dentre as modificaçóes políticas, sociais e culturais que mobilizaram o Brasil ao longo do século XIX, uma delas é, evidentemente, a formação de uma "identidade nacional" manifesta sob diferentes contextos estruturais, entre os quais a questão constitucional será um tema fundamental.

E aqui, quando utilizamos a expressão 'questão constitucional', o sentido nela expresso tem um significado mais largo do que aquele que, em princípio, poderíamos reduzir ao processo de elaboração e fixação de uma Carta Constitucional.

Nesse sentido, o que estamos denominando "politeía tropical” é um duplo processo que envolve, antes de qualquer outra imposiçáo, o sentido atribuído na tradição do pensamento antigo ao termo politeía, isto é, a extensão semântica entre a constituição política, o princípio de cidadania e os direitos e os deveres do Estado e do cidadão, de tal modo que tenhamos uma possibilidade de leitura e compreensão da presença intensa dos autores clássicos no contexto da formação do Brasil como nação, ao longo do século XIX. ${ }^{1}$

Sob esse aspecto, a importância do século XIX para a história da recepção dos clássicos gregos na vida política brasileira e as traduçóes que são elaboradas ao longo desse período, além de serem um fato inequívoco, podem nos auxiliar na compreensão do processo de formação da ideia de 'pátria', de 'naçấo', de 'brasilidade', e, se nos ativermos à presença da tradução de autores clássicos, veremos que eles estáo presentes em momentos chave da vida política brasileira e que podem ser vistos, muito claramente, a partir de três acontecimentos históricos vitais na construção da concepção de 'nação brasileira': [i] a alteração do estatuto político, de Colônia a Reino Unido de Portugal e Algarves, em 1808, com a vinda da Corte portuguesa para o Brasil; [ii] a emancipação política com a independência de Portugal, em

1 E aqui parece-nos, ainda, oportuno lembrar que o termo não é usual na língua grega arcaica, sendo encontrado na prosa jônico-ática a partir da segunda metade do século $\mathrm{V}$ a.C, inicialmente nos textos dos historiadores e, em seguida, frequentemente, nos textos de filósofos e oradores. Ademais, o termo politeía é uma palavra de difícil tradução, cujo significado está interligado aos de pólis e polites: se a pólis se constitui em uma "comunidade de cidadãos", a politeía, enquanto modo de vida do cidadão, só ganha sentido no interior da pólis. Nesse sentido, a politeía se manifesta em dois aspectos vitais do pensamento político grego: o direito de cidadania e a forma de governo, o regime político, e enquanto direito de cidadania, a politeía determinava os direitos políticos do cidadão e sua participação na estrutura geral da pólis, não como um ato meramente jurídico entre o indivíduo e o Estado, mas como um corpo vivo, onde cada cidadáo participa da cidadania. Sobre o tema, veja-se, por exemplo: Ehrenberg 1980: 44-77; Manville 1990; Cataldi, 2004, e para uma análise do aparecimento e da difusão do termo politeía, veja-se Bordes 1982: 18-33. 
1822, e, [iii] a constituição de um "império constitucional" - e seus desdobramentos na guerra do Paraguai, na Abolição da Escravidão e na mudança Constitucional Republicana, em 1889.

Assim, a publicação, no Rio de Janeiro, em 1814, pela Impressão Régia, da tradução de Silvestre Pinheiro Ferreira das Categorias de Aristóteles - para servir de texto base para suas Preleçôes Filosóficas, ministradas a partir abril de 1813, no Real Colégio de São Joaquim -, a tradução do idílio de Meleagro de Gadara, A Primavera, por José Bonifácio de Andrada e Silva, publicada em Lisboa, em 1816, e as traduçóes da História da Guerra do Peloponeso de Tucídides, do Prometeu Acorrentado, de Ésquilo e da Odisséia, de Homero, feitas por D. Pedro II, marcarão, definitivamente, a presença e a importância dos clássicos gregos na formação política brasileira no século XIX², espelhando em seus contextos a expressão de momentos decisivos de nossa formação. Os elos entre esses três homens públicos e a tarefa de tradutor exercida por cada um deles, em diferentes momentos da vida política brasileira no século XIX, não são apenas intelectualmente convergentes mas espelham uma "visão de mundo" na qual o pensamento antigo constitui-se, tal como sugerido por Machado de Assis, em Esaú e Jacó, como um "par de lunetas" que nos permitem uma mais larga compreensão da emergência do Brasil como nação.

Não nos parece mero acaso o fato de Silvestre Pinheiro Ferreira e José Bonifácio de Andrada e Silva escreverem, em 1813, em O Patriota - jornal editado no Rio de Janeiro, e publicado pela Impressão Régia ao longo dos anos de 1813-1814 -, artigos sobre metalurgia e química; de Pinheiro Ferreira - o que já estava prenunciado em outro artigo publicado em $O$ Patriota, sobre a "gramática filosófica" que estaria na base de suas preleções -, traduzir e publicar as Categorias, em 1814, enquanto em 1816, José Bonifácio traduz e publica, em Lisboa, o idílio de Meleagro de Gadara; e que em 22 de novembro de 1843, em carta de Silvestre Pinheiro Ferreira a D. Pedro II, publicada pelo Diário do Rio de Janeiro ${ }^{3}$, reencontremos os problemas da 'constituição' e de uma monarquia constitucional, bem como a ideia de 'confederação' como modo de manutenção de um 'governo imperial', o que, sob um sentido alargado, poderá ser visto como uma reunião temática de nossos três tradutores, agora mediados na sequência política, pelo Imperador do Brasil, às voltas, ao longo do século XIX, com o

2 Para uma análise das relaçôes entre as Preleçôes Filosóficas, a tradução das Categorias, e a tradução do idílio de Meleagro de Gadara por José Bonifácio de Andrade e Silva, veja-se Moraes Augusto 2010: 313-350 e Moraes Augusto 2012/2013: 128-135.

3 Cf. Ferreira 1843: 1. 
Prometeu Acorrentado, de Ésquilo e com a História da Guerra do Peloponeso, de Tucídides, e, posteriormente à queda da monarquia, com a tradução da Odisséia, de Homero.

Nesse estudo - que é parte de uma análise mais larga, ainda em fase de redação e na qual estão incluídas e relacionadas as traduções acima indicadas -, nos deteremos na obra de Silvestre Pinheiro Ferreira, referente aos anos de 1813-1814, editadas no Rio de Janeiro, pela Impressão Régia: os artigos publicados no jornal $O$ Patriota, as Preleçôes Filosóficas, e a tradução das Categorias de Aristóteles, que, além de ser a primeira traduçáo de um autor antigo impressa no Brasil, completa 200 anos de publicação em 2014, procurando apontar em nossas análises, a funçáo que o pensamento antigo cumpriu na consolidaçấo da 'brasilidade' no século XIX. Daí o nosso esforço de uma leitura que, atenta ao tema da politeía, possa apontar para uma política fundada nas categorias da língua como base da 'nacionalidade'.

\section{As categorias da língua como base da 'nacionalidade': Silvestre Pinheiro Ferreira, as Preleçóes Filosóficas e a funcionalidade da tradução na crítica filosófica.}

Silvestre Pinheiro Ferreira chegou ao Rio de Janeiro, provavelmente, em 1809 ou $1810^{4}$, vindo de Londres como funcionário do Ministério dos Negócios Estrangeiros, ficando sem um cargo remunerado até 13 de maio de 1811, quando foi nomeado deputado da Junta do Comércio, e em 17 de fevereiro de 1815, diretor da Junta de Direção da Real Tipografia e da fábrica das cartas de jogar, da qual também era integrante José Maria Lisboa, o futuro Visconde de Cairus . Nesse período, Pinheiro Ferreira não só publicou trabalhos científicos e filosóficos no jornal O Patriota, ministrou, no Real Colégio de São Joaquim, suas Preleçôes Filosóficas e traduziu as

41810 é a data indicada por Inocêncio Francisco da Silva, em seu Dicionário Bibliográfico Português (Silva, 1862, p. 259-273, v.7), e aceita por muitos dos comentadores de sua obra para a chegada de Pinheiro Ferreira ao Brasil, entretanto, Maria Beatriz Nizza da Silva, após um rastreamento das cartas e ofícios enviados por ele a António de Araújo de Azevedo, futuro Conde da Barca, assinala que em 1809 Pinheiro Ferreira chegou a Londres, de onde, neste mesmo ano, embarcou para o Rio de Janeiro. Nesta cidade teria tido dificuldades para encontrar um posto remunerado, pois, "tendo chegado ao Brasil em 1809, ainda em maio de 1811 estava desempregado, vivendo de uma escassa pensão de 53\$000.” Cf. Silva 1975: 11-32. Sobre as relaçôes de Pinheiro Ferreira com o Conde da Barca, cf. Silva 1975: 9-45; Lima 2006: 335-356.

5 Cf. Silva 1975: 32. Para as possíveis funções exercidas junto à Real Tipografia, Cf. Silva 1975: 44-45. 
Categorias de Aristóteles, mas, também, redigiu, a pedido de D. João VI, o projeto de reforma da monarquia portuguesa, divulgado sob o título de Memórias politicas sobre os abusos gerais e modos de os reformar e prevenir a Revolução Popular, redigidas por ordem do Principe Regente - 1814/1815. ${ }^{6}$

Em 1819, foi escolhido para representar Portugal junto à comissão luso-britânica para a extinção do tráfico de escravos, mas, em meados de 1820, quando deveria seguir, como representante do governo português, para os Estados Unidos, a revolução liberal que explodira em Portugal e a crise política de fevereriro de 1821, no Rio de Janeiro, levou D. João VI a nomeá-lo Ministro do Exterior e da Guerra, ${ }^{7}$ condição na qual regressará a Portugal com o monarca, afastando-se do governo em 1823, e seguindo para Paris num exílio voluntário ${ }^{8}$ - onde poderá dedicar-se à filosofia e ao aprofundamento de suas teses políticas -, de onde só retornará a Portugal, em 1842, morrendo em Lisboa, em julho de 1846.

${ }^{6}$ As idéias aí apresentadas e sugeridas por Silvestre Pinheiro Ferrreira, já prevendo que se o Princípe Regente retornasse a Portugal o Brasil se emanciparia, eram demasiadamente arrojadas para tornarem-se públicas, e as observaçóes feitas para sua impressão são extremamente severas: "serão impressos [as memórias escritas por SPF] debaixo de todo o segredo, em presença de um criado de V.A.R., só com o administrador da Impressão Régia e os artífices necessários, queimadas ali mesmo as provas, desmanchadas as formas e tirados unicamente os exemplares precisos para as seguintes pessoas: conselheiros de Estado, o bispo capeláo-mor, os titulares maiores de 30 anos, os desembargadores do Paço, os conselheiros da Fazenda, os desembargadores da Casa da Suplicação, os deputados da Junta do Comércio e Mesa do Erário”. Apud: Silva 1975: 44. Cf. "Proposta sobre o regresso da corte para Portugal e providencias convenientes para prevenir a revolução, e tomar a iniciativa na reforma política”, 22 de abril de 1814. 3f. (FBN, Seção de Manuscritos, I-31,21,010.) e a edição das Memórias pela Revista do IHGB, v.47, 1884. A PUC-Rio, publicou uma versão ortograficamente atualizada, na Coleçáo Textos Didáticos do Pensamento Brasileiro, sob a Direção editorial de Celina Junqueira, em 1976. Essas Memórias foram, posteriormente, revistas e refinadas em seu exílio parisiense e lá publicadas. Cf. Ferreira, 1831 e 1834, Observaçōes sobre a Carta Constitucional do Reino de Portugal e sobre a constituição do Império do Brazil, publicada em 1831, com uma Advertência e em 2a edição, revista, em 1834.

7 A narrativa acerca de sua participação no governo, na fase brasileira, será descrita nas Cartas sobre a revolução do Brasil, publicadas nos Anais da Biblioteca Nacional, 1877, v. II e III. Veja-se, também, Memórias e cartas biográficas versando sobre os fatos politicos sobrevindos no Rio de Janeiro à revolução constitucionalista do Porto e Lisboa, desde suas repercussöes e consequentes sublevaçôes de fevereiro e abril de 1821 até o regresso de D. João VI com a corte para Portugal. Seção de Manuscritos da FBN, I-31, 21,009.

8 Em seu longo exílio parisiense Silvestre Pinheiro Ferreira dedicar-se-á à Filosofia e à reflexão política, tendo comentado as constituiçôes brasileira e portuguesa, e publicando, em 1834, o Manual do cidadão em um Governo Representativo, em 3 volumes, além de seu Essai sur la psychologie, em 1826, onde encontramos a edição em grego com a respectiva traduçáo dos textos gregos e latinos nele citados. 


\subsection{Os 'escritos patrióticos': as modulaçóes filosóficas entre a gramática e a ciência}

O Patriota, jornal literário, politico e mercantil, publicado ao longo dos anos de 1813-1814, no Rio de Janeiro, pela Impressão Régia, foi fundado por Manuel Ferreira de Araújo Guimarães, com uma proposta arrojada, contendo seções temáticas divididas em diferentes áreas do conhecimento - Artes, Agricultura, Hidrografia, Medicina, Literatura, História, Política, Comércio, e, ainda, uma Seção para as obras publicadas na Corte no mês de edição do jornal ${ }^{9}$ -, e contando, dentre os seus redatores, com nomes relevantes da vida política e intelectual de entâo: Borges de Barros, Silva Alvarenga, Garção Stockler, Mariano Pereira da Fonseca, Camilo Martins Lage, José Bonifácio de Andrada e Silva, José Saturnino, José Bernardes de Castro, Silvestre Pinheiro Ferreira ${ }^{10}$, o jornal trará "luzes para o Império", ${ }_{1}^{11}$ marcando, assim, não só as mudanças

9 Essas são as seções delimitadas no primeiro número do jornal, nos números seguintes elas seriam mantidas com pequenas alteraçôes que atendiam à classificação dos artigos contidos em cada número e onde encontraremos as seçôes de Matemática, Estatística, Mineralogia, Química, Eloquência, Agricultura, Geografia, Navegação, Hidrografia e Topografia, além de uma seção de Necrologia que aparecerá em alguns números.

10 Aqui, é oportuno lembrar que o jornal, embora tenha suas ligaçôes com o estado português bem delimitadas - é editado pela Impressão Régia, que concedia o "Com Licença”, indicando sua aprovação pelo Desembargo do Paço, tem entre seus colaboradores figuras vinculadas à estrutura de poder no Reino Unido de Portugal e Algarves -, não foi subscrito financeiramente pelo Estado, mas a um processo de colaboração mantido por seus subscritores financeiros. É sob essa ótica que muitos historiadores têm chamado a atenção para o fato de que entre seus colaboradores estão alguns importantes "herdeiros e continuadores do absolutismo ilustrado e fundadores do liberalismo político, no mundo luso-brasileiro"(Morel 2007: 29), como é o caso de José Bonifácio e Silvestre Pinheiro Ferreira, e que o projeto do jornal expressava o contexto de conflitos internos do Estado português, envolvendo questôes relativas ao fato de o Rio de Janeiro ser a sede da Monarquia e que, dentre os nomes contidos na primeira lista de assinantes, encontremos o Conde e a Condessa de Linhares, falecido no Rio de Janeiro, em janeiro de 1812, com suspeita de envenenamento, por assassinato ou suicídio, após conflitos com o Princípe Regente. Nesse sentido, o grupo de colaboradores do jornal estava ligado a D. Rodrigo de Sousa Coutinho, o Conde de Linhares, e a seu projeto iluminista e modernizador do império português: "Nesse contexto, o surgimento do periódico O Patriota explica-se justamente pela morte de d. Rodrigo de Sousa Coutinho[...]. Ou seja, aparece como uma espécie de obra póstuma de d. Rodrigo, ou tentativa de rearticulação de grupos e indivíduos que compunham e atuavam diretamente no Estado, identificados, de um modo geral, com a perspectiva reformista e com a ênfase no Brasil como local privilegiado no conjunto da naçáo portuguesa, ou com o poder pessoal do conde de Linhares" (Morel 2007: 36). Para uma análise do contexto político e intelectual e dos redatores e leitores de O Patriota, cf. Morel 2007: 15-39; Ferreira 2007: 41-66, e Lyra 1994.

11 A importância intelectual d'O Patriota, definida por Carlos Rizzini como "a melhor publicação literária não apenas da Colônia, mas do Reino, do Império sob Pedro I e 
Politeía Tropical: a recepção dos clássicos, a tradição política no Brasil do século XIX e a tradução das Categorias aristotélicas por Silvestre Pinheiro Ferreira

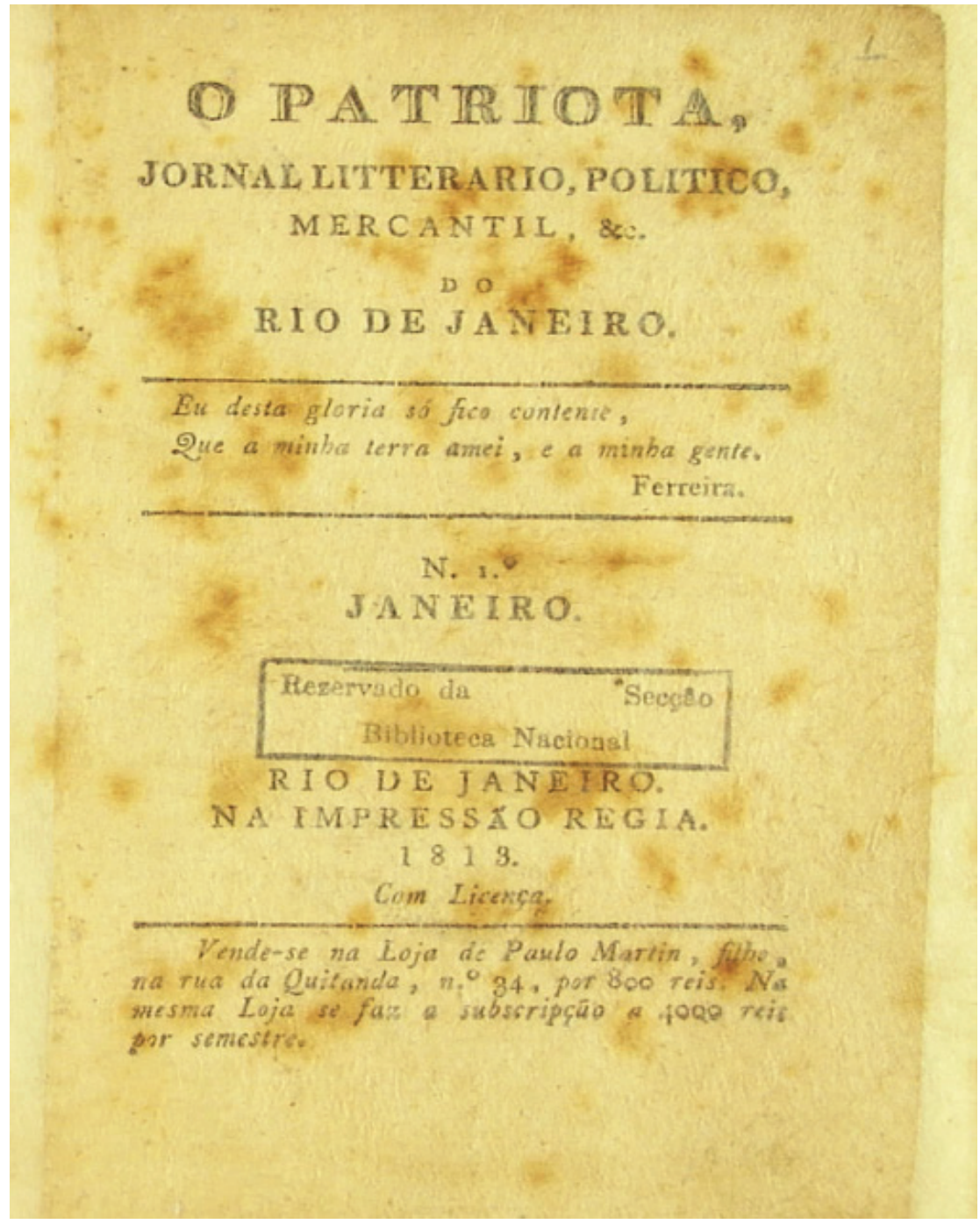

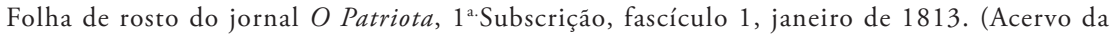
Fundaçāo Biblioteca Nacional, Rio de Janeiro) 
políticas instauradas pela nova condição política de Reino em detrimento da velha Colônia, mas, também, as novas estratégias alavancadas com a implantação da tipografia e com a circulaçáo de ideias através de livros agora impressos no Brasil. ${ }^{12}$

Nesse sentido, as palavras de abertura do editor no primeiro número do jornal já apontam para uma estratégia intelectual - que nos parece comum ao projeto de Pinheiro Ferreira em suas Preleçôes -, que consistia na extensão da "invenção das letras" à "contemporaneidade dos séculos", de modo que daí pudesse advir uma 'nação':

da Regência” (Rizzini 1957: 159), foi assinalada por muitos de seus comentadores, veja-se, sobretudo, Moraes e Camargo 1993; Salgado 2007; Kury 2007, e Alcides 2007. A expressão "luzes para o Império" é parte do título do capítulo As luzes para o Império: história e progresso nas páginas de O Patriota, de Manuel Luiz Salgado Guimarães, 2007: 67-101 evocando a presença das teses 'iluministas' em todo o projeto do jornal.

12 A Impressão Régia, e o que ela publicou entre 1808 e 1821, reflete bem as mudanças que foram alavancadas com a vinda da Corte para o Rio de Janeiro, pois, além dos atos oficiais do governo, foram editadas obras de caráter histórico, científico, literário e filosófico, valendo notar também a qualidade gráfica das publicaçôes: "A Impressão Régia foi uma excelente editora: publicou uma dezena de livros de real valor cultural, fez conhecer os poetas famosos, em moda em Portugal, imprimiu versos dos nossos, lançou o romance e a novela no Brasil, resolveu o problema do livro didático para o ensino superior inaugurado no Rio de Janeiro e cumpriu sua missão principal quanto à legislação. Não exagero afirmando que somente na segunda metade do século XIX, quando as editoras de Leuzinger e Laemmert estavam no auge, é que tivemos editoras comparáveis. [...] Examinando esses livros, esses folhetos de poucas páginas, ficamos admirados com a qualidade dos impressos. São composiçóes de uma sobriedade, de um bom gosto de fazer inveja aos nossos impressores atuais. Raramente, muito raramente na verdade, a tipografia brasileira atingiu um padrão tão alto de elegância e beleza. São composiçôes comparáveis e dignas dos grandes renovadores da tipografia, os Didot, os Bodoni. [...]. Não é preciso procurar muito para encontrar verdadeiras obras-primas tipográficas nessa vasta produção. Duas ou três obras entretanto destacam-se. São o Ensaio sobre a critica, os Ensaios moraes, ambos de Alexander Pope, traduzidas pelo conde de Aguiar, e os dois volumes da Memória da vida publica do lord Wellington, de José da Silva Lisboa. [...] A impressão é nítida e clara, a distribuição do texto e das notas nas páginas, a proporção das margens, tudo enfim, nessas obras [...] é perfeito.[...] Era um mestre o tipógrafo que compôs essas páginas de rosto. Soube dar destaque ao texto principal e deixar na sombra os dizeres complementares. Obteve beleza e harmonia sem truques e sem enfeites supérfluos. São páginas tão simples e perfeitas que nada se poderia mudar para melhorá-las." (Moraes 2006: 130-31). Veja-se, também, Lima 2006: 557-569. Acreditamos que a avaliação de Borba de Moraes vale, também, para a edição da tradução das Categorias e das Preleçôes Filosóficas, e d'O Patriota. 
"É uma verdade, conhecida ainda pelos menos instruídos, que sem a prodigiosa invençáo das letras, haveriam sido muito lentos os progressos nas Ciências, e nas Artes. [...] Os homens de todos os Séculos são contemporâneos, e o sábio no seu gabinete instrui-se ainda hoje com os Arquimedes e Apolonios, recrea-se com os Homeros e Anacreontes, consulta os Tucídides e os Lívios; admira a eloquência dos Demóstenes e Cíceros; e ligando eras interrompidas por longas séries de calamidades, salva através das irrupçôes dos Bárbaros, voa a despeito das injúrias do tempo, e prende remotíssimos anéis da cadeia não interrompida dos erros do entendimento, e dos crimes do coração humano. Mas instruídos pela física de que os raios do Sol, que dispersos aquecem apenas os corpos duros, juntos em um foco derretem os mais densos metais, os sábios se propuseram a comunicar-se reciprocamente suas luzes, para que da uniáo delas resultasse aquele intenso calor, que vencesse a frieza da preguiça, e a dureza da ignorância. As suas primeiras obras abriráo o caminho a outras mais perfeitas." ${ }^{13}$

E, em uma concepção em que a história se torna sempre "contemporânea" pela via das "letras", a 'ideia de nação' resultará, portanto, da compreensão do processo político através da 'maleabilidade' do conhecimento que, pelo "intenso calor" daí resultante, permitirá que a "frieza da preguiça" e a "dureza da ignorância" sejam vencidas. ${ }^{14} \mathrm{O}$ que o nome "patriota", de certo modo já explicitado na epígrafe ao título do jornal - "Eu desta glória só fico contente,/ Que a minha terra amei e a minha gente." ${ }^{15}$-, vem, de certo modo corroborar, com uma pluralidade de sentidos que tem sido largamente estudada pelos

13 Cf. O Patriota, S1,1, I, 3-4,1813; grifos nossos. Para referenciar O Patriota, seguimos o Índice de $O$ Patriota, elaborado por Diana Zaidman, com os dados na seguinte ordem: Subscrição, fascículo, mês, página e ano. Nas citaçôes dos textos do século XIX, as transcriçóes foram atualizadas apenas na ortografia, mantivemos tanto a pontuação original, quanto as maiúsculas, tal como utilizadas pelo autor no original, mesmo nas citaçốes não destacadas.

14 Vale notar aqui o sentido 'químico' da metáfora, o que parece, mais uma vez, aproximar o projeto silvestriano - pois os dois 'temas patrióticos' de nosso autor unem a gramática filosófica à teórica do calórico -, analisado a partir dos três textos do autor publicados no jornal $O$ Patriota, e que poderia também nos fazer suspeitar ser ele um dos autores da Introdução, no primeiro número do jornal.

15 Versos do poeta quinhentista português António Ferreira, em Aos bons engenhos. 
especialistas, ${ }^{16}$ é o alargamento da perspectiva corográfica como elemento dimensionador de sua dimensão intelectual, política e moral. ${ }^{17}$

A essa 'política epistolar' vale acrescentar ainda que o redator responsável divulga os livros publicados mensalmente na Corte, bem como noticia eventos relacionados às ciências, estabelecendo, também, uma dialógica com a cultura. Já no primeiro número encontramos a implementação das 'Cartas dos leitores", que aparece como uma chave interlocutória entre o responsável pelo jornal e seus colaboradores. E será exatamente nesse enclave que aparecerá, no primeiro número d'O Patriota, a primeira colaboração de Silvestre Pinheiro Ferreira: na Seção denominada 'Literatura', entre odes, um epigrama, uma "Lira inédita", de Tomás Antônio Gonzaga, e as "Máximas, Pensamentos e Reflexôes Morais", escritas por "Um brasileiro", encontraremos, ao final da seção, a carta dirigida por Pinheiro Ferreira ao redator d'O Patriota, abordando "uma questão gramatical sobre as sílabas". ${ }^{18}$

Referindo-se a uma questão gramatical, posta em uma "Sociedade Literária" na qual ele se encontrava, tendo sido indagado acerca do que era "sílaba", Pinheiro Ferreira proporá, em sua carta ao redator do jornal, dar publicamente, isto é, dar por escrito no jornal, a seguinte resposta:

"Chama-se sílaba o concurso de qualquer vogal ou ditongo com a sua figurativa e consoantes que se seguem até a figurativa de outra vogal ou ditongo em uma mesma palavra simples." ${ }^{19}$

A seguir, irá definir os ditongos como sendo o "concurso de uma vogal de meio tom com outra de tom inteiro", explicitando-os em um gráfico contendo duas colunas, uma com "exemplos" e outra com "contrastes", e a "sílaba figurativa" como sendo "a consoante muda que precede uma vogal", sozinha ou com uma consoante liquída, classificando, entáo, as mudas como sendo "simples" ou "compostas" (S 1, 1, I, 94, 1813).

\footnotetext{
16 A questão dos usos dos termos 'patriota' e 'pátria' no âmbito d'O Patriota possui já uma larga bibliografia, dentre a qual os textos de Morel 2007:15-39; Kury, 2007: 10-12, 141-157; Guimaráes 2007: 78-80, apontam para elementos importantes da questáo.

17 Sobre a dimensão intelectual e política do termo 'patriota' e a herança iluminista no jornal homônimo, cf. a análise de Guimarães 2007: 67-101.

18 No corpo do texto do jornal, a separação entre um artigo e outro, em uma mesma seção, é feita apenas por uma linha e abaixo dela a chamada epistolar: "Senhor redator", a indicação de que se trata de uma "questão gramatical sobre as sílabas, por S. P. F." nos é dada no 'Índice' do jornal. Cf. O Patriota, S1, 1, I, 93-95,128,1813 e no Índice Geral, publicado no último volume de 1814, Cf. S3, 6, XI-XII, 5,1814.
}

19 Ferreira, O Patriota, S1, 1, I, 93-94,1813. 
Ao final da carta, Pinheiro Ferreira dirá que essas definiçóes podem ser úteis, seja por sua "exatidão", seja pelo fato de despertarem em "alguém [ou a algum leitor?] a lembrança de outras melhores", daí ter tomado a "liberdade" de enviá-las ao redator para que, se "julgar que não são indignas dessa honra", publicá-las no referido "periódico", despedindo-se com a manifestação de "estimação" e "atenta veneração" (S 1, 1, I, 95,1813).

Aqui, pensamos que, no artíficio das "sílabas", sua definição, a função exercida pelos ditongos - um encontro de "tonalidades" -, e a associação entre vogais e consoantes, o que está em causa é o processo no qual as sílabas devêm 'palavras' e 'discursos', articulando e legitimando a tese subscrita na Introdução do primeiro número d'O Patriota, entre a "invenção das letras" e a constituiçáo da 'pátria' como substrato intelectual, corográfico e político de um Estado (ou de uma nação) emergente. ${ }^{20}$

Essa hipótese, se acompanharmos as publicações de Pinheiro Ferreira em O Patriota, não só, parece-nos, será confirmada, mas ganhará um estatuto próprio ao ser incluída em uma seção à qual atribuir-se-á a denominação de "Gramática Filosófica" (S1,4, IV, 21-29,1813), vindo na sequência das seçóes do jornal, logo após Literatura. ${ }^{21} \mathrm{O}$ estudo mais longo e detalhado, em relação àquele publicado em janeiro de 1813, com classificaçóes expostas graficamente, estabelecerá as 'categorias' gramaticais que compóem a língua e consequentemente subjazem aos discursos, será chamado por S.P.F. de "filosofia das línguas" (S1, 4, IV, 21, 1813).

20 O que, afinal, significaria "sociedade literária"? O contexto do jornal e o grupo de intelectuais a ele vinculados?, o ambiente no qual as Preleçôes estavam sendo gestadas, já que pelas indicaçôes que temos elas teriam tido o seu início em 26 de abril de 1813, ou ainda, as sociedades científicas e literárias existentes no Rio de Janeiro, tal como a Sociedade Literária do Rio de Janeiro, fundada por Manoel Ignácio da Silva Alvarenga, no final do século XVIII, localizada no andar térreo da casa do poeta, tendo por objetivo a troca de conhecimentos entre seus associados, e na qual buscou integrar a literatura à política? E é oportuno sublinhar que Silva Alvarenga também participou como autor em O Patriota, tendo falecido em 1814. Sobre esta questâo, cf. Candido 1976: 78, Moraes Augusto 2012/2013: 126-128.

21 Como a seção 'Gramática Filosófica' vem na sequência da seção 'Literatura', e como naquela altura a 'gramática filosófica' era considerada como parte da 'literatura', as relaçóes entre ambas parecem-nos conter certa ambiguidade; e como a seção 'Gramática Filosófica' só aparecerá em dois números d'O Patriota - nas S1, 4, IV, 1813 e S1, 5, V, 1813 -, e a de Literatura em quase todos os números - exceto no número S3, 4,VII-VIII,1814 -, é consequente pensarmos que ela estava diretamente articulada ao projeto silvestriano das Preleçöes, uma vez que ganha a explicitação de que seu autor dedica-se à "filosofia das línguas", delimitando, de certo modo, uma primeira distinção entre 'filologia' e 'filosofia'. 


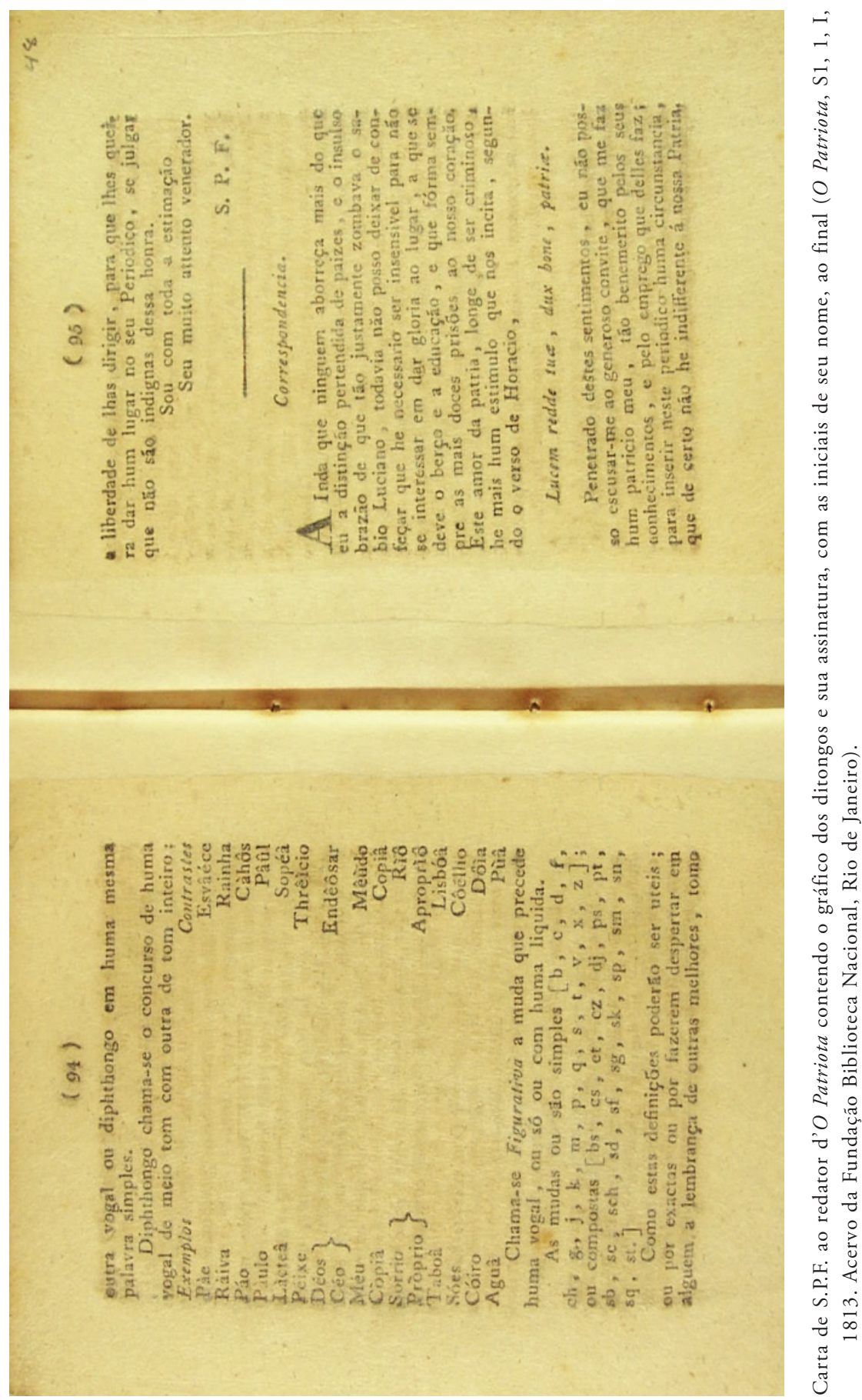


Apresentando uma classificação pormenorizada das sílabas e das palavras, numeradas no gráfico e em seguida pela remissão desses números, e explicitadas no texto, definirá agora as sílabas como sendo compostas de vogais e consoantes, dividindo-se, as primeiras, em simples e ditongos, e, as segundas, em figurativas e adicionais - guturais: h, ch, gh, g, k; palatinas: ill, j, ll, gn; maxilares: $\mathrm{j}, \mathrm{x}, \mathrm{tx}, \mathrm{dj}, \mathrm{sh}, \mathrm{s}, \mathrm{n}, \mathrm{l}, \mathrm{r}, \mathrm{rr}$; dentais: $\mathrm{dz}, \mathrm{tz}, \mathrm{ss}$, th, ç, d ,t; labiais: b, p m, w, ph; labio-dentais: $\mathrm{f}, \mathrm{v}-$, que podem ser simples ou compostas, sendo figurativas as consoantes, simples ou compostas ( $\mathrm{S} 1$, 4 , IV, 23, 1813), que precedem, em uma palavra simples, a uma vogal; as consoantes "que se seguem até a figurativa da vogal seguinte chamam-se adicionais" (Cf. S1, 4, IV, 25, 1813).

Por outro lado, as palavras serão divididas em 6 classes: verbo, nome substantivo e adjetivo -, advérbio, conjunção, preposição e interjeição, que serão assim definidas:

[i] Verbo são aquelas "palavras, que afirmam ou negam a existência real, ou hipotética do significado, em tempo determinado ou indeterminado"; e podem ser, em função do fato expresso pelo verbo, ativo ou "transeunte". Chama-se "ativo" o verbo que exprime um fato "como razão de outro fato", (ex."Firo") ; e "traseunte" se o efeito da açẫo verbal da qual "esse fato é razão, se verifica em outro sujeito" (ex."Cortei”), mas, se a ação se exprime no mesmo sujeito, "chama-se intranseunte" (ex."Cubro-me"), e, "se o fato, que o verbo exprime, se considera como efeito, chama-se o verbo passivo" (ex. "Foi ferido"); e, se a ação verbal não é considerada "nem como razão, nem como efeito; mas como um simples estado do sujeito", diz-se que o verbo é "neutro".

[ii] Nomes são aquelas palavras que "se denotam qualidades comuns a muitos indivíduos, chamam-se Apelativos (ex. "Animal, Ferro")" e podem expressar de modo absoluto ou relativo, quantidade, qualidade, lugar, tempo, causa, razáo, motivo, ocasiáo, modo, instrumento, matéria e efeito. Os demais nomes "são chamados de próprios"(ex. "Pedro, Roma"). Os nomes podem ser:

[ii.i] substantivos, que são aquelas palavras usadas para "designar o agente da significação de algum verbo", dos quais Pinheiro Ferreira dará como exemplos: homem, corpo, alma, entendimento, virtude, vício e força. (Cf. S1, 4, IV, 26, 1813);

e,

[ii.ii] adjetivos, que são aquelas palavras "que só servem a especializar os Substantivos", e são exemplificados com: grande, honrado, feliz. (Cf. S1, 4, IV, 26, 1813);

[iii] Advérbios são "as palavras, que se empregam para especializar a significação de algum verbo, ou de algum adjetivo"; 
[iv] Conjunções são aqueles termos "unicamente destinados a estabelecerem a relação de diferentes frases, e também às vezes as de diferentes partes de uma mesma frase entre si", e podem ser: copulativa, aditiva, ilativa, causal, concessiva, condicional restritiva, distintiva, e adversativa;

[v] Preposiçóes são aqueles termos usados "para estabelecer a relação de algumas palavras de uma mesma frase entre si”;

$\mathrm{e}$, finalmente, as

[vi] Interjeições, definidas como "aquelas, que, não significando nada, ou que além da sua significação, exprimem só pelo tom com que se pronunciam, o sentimento da pessoa, que delas se serve", e podem ser interrogativas, se supóem uma resposta; se não, são chamadas de exclamativas, variando em ambas as possibilidades a expressão de sentimentos de alegria, dor, indignação, compaixão, tenura, exortação, invocaçãa, chamamento e pergunta. (Cf. S1, 4, IV, 23-26, 1813)

A "gramática filosófica" de Silvestre Pinheiro Ferreira conterá não só exemplos das palavras e termos definidos pelo autor, mas, também, um gráfico do "sistema dos principais tons das Línguas Grega, Latina, Italiana, Portuguesa, Espanhola, Francesa, Inglesa, Holandesa, Alemã, dispostos conforme as suas afinidades" (Cf. S1,4, IV, 24, 1813), indicando que seu projeto gramatical está incluído em um contexto no qual a noção de "afinidade" é algo que importa em seu veio reflexivo entre a "arte de falar" e a "arte de pensar", e que será esclarecida como sendo "atração química"22, em sua Memória sobre um novo princípio da Teórica do Calórico, publicada em O Patriota, S2, 1, I, 3-11, 1813.

A introdução de uma "gramática filosófica" em O Patriota coloca mais uma vez o contexto discursivo do jornal em uma dimensão iluminista - e aqui não seria inoportuno relembrar que as "gramáticas filosóficas da língua portuguesa" surgem em Portugal na segunda metade do século XVIII, sob a influência da "l'Art de Parler", da Grammaire Genérale et Raisonnée de Port-Royal e da Logique et l'Art de Penser, de Antoine Arnault e Pierre Nicole. A primeira gramática a portar o título de 'filosófica' foi a de Bernardo de Lima e Mello Bacelar, Grammatica Philosophica e orthographica racional da Lingua Portugueza, publicada em Lisboa, na Officina de Simão Thaddêo Ferreira, em 1783, onde a 'gramática filosófica' é definida como sendo uma

22 É assim definida no Índice das vinte e duas primeiras preleções, Cf. Preleçôes Filosóficas, $\$ 165$. 
Politeía Tropical: a recepção dos clássicos, a tradição política no Brasil do século XIX e a tradução das Categorias aristotélicas por Silvestre Pinheiro Ferreira

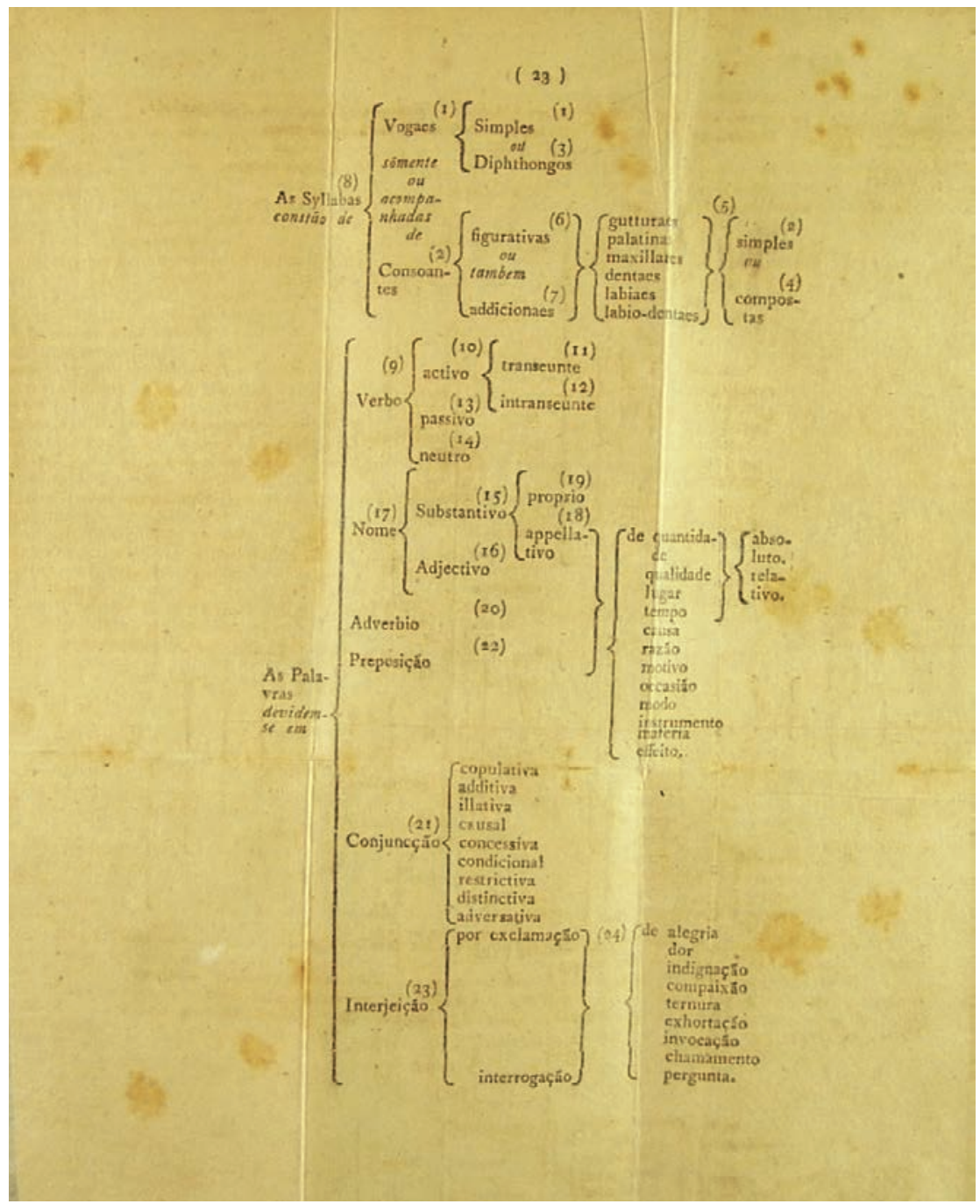

Quadro classificatório das sílabas e das palavras proposto por SPF em sua Gramática Filosófica. O Patriota, S1, 4, IV, 23, 1813. (Acervo da Fundação Biblioteca Nacional, Rio de Janeiro) 


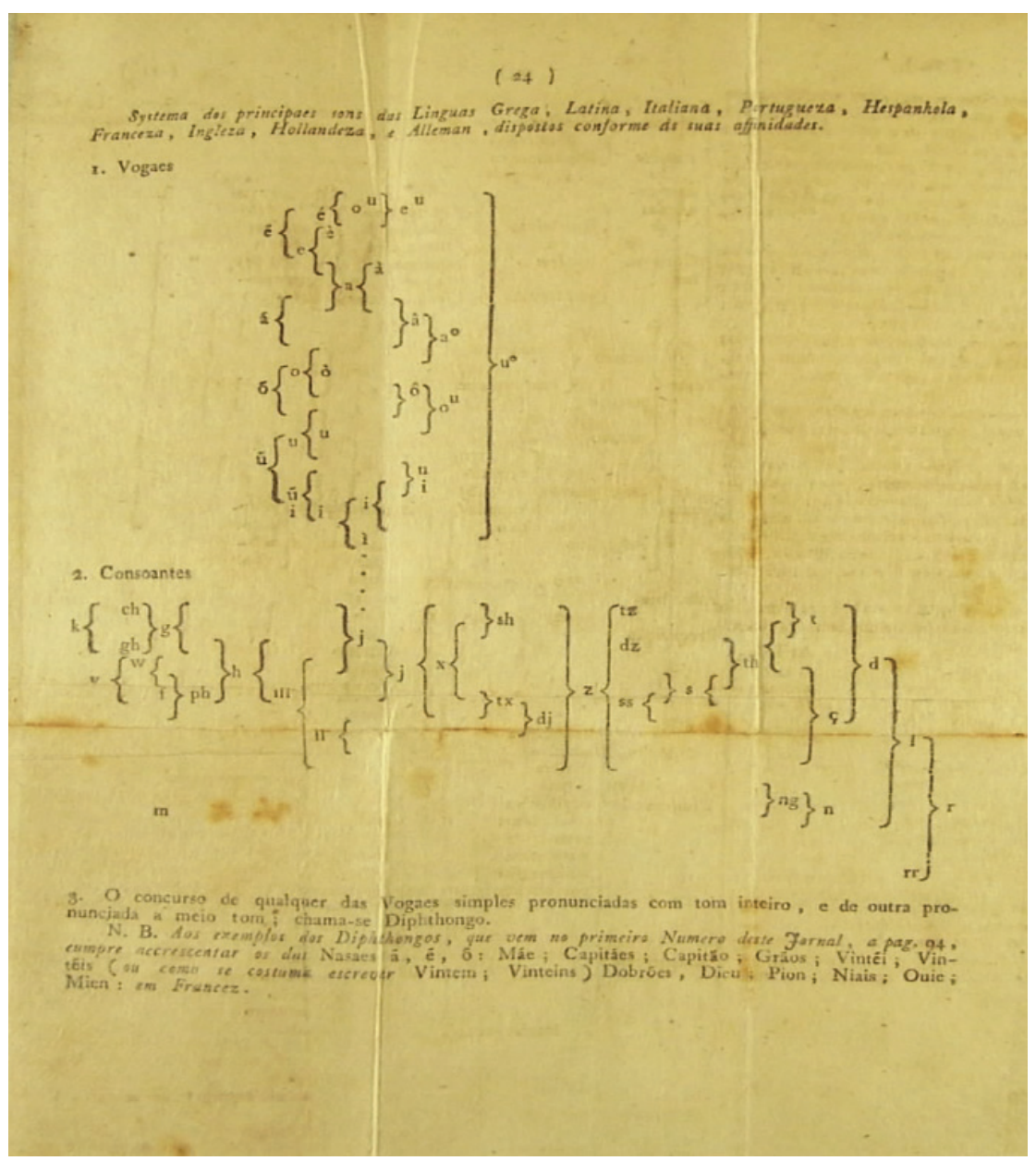

Sistema dos principais sons das línguas grega, latina, italiana, portuguesa, espanhola, francesa, inglesa, holandesa e alemã dispostas conforme as afinidades. (O Patriota, S1, 4, IV, 24, 1813. Acervo da Fundação Biblioteca Nacional, Rio de Janeiro) 
“[...] coleção de Leis, com que arrazoadamente fabricamos e dispomos os sons, que comunicam aos outros os nossos conceitos [...]. Começaram os homens a traficar; e comunicar-se mais, e mais; e para este fim inventaram cópia de sons. Destes, e dos inatos derivaram outros: e determinando as leis de os colocar vieram desta sorte a ter uma perfeita língua de comunicação, cujo arrazoado, ou discurso regulamentado, se chama Gramática Filosófica. Daqui se segue 1. que os sons regulados são, o objeto, e partes da Gramática Filosófica: 2. que o seu fim é a comunicação, que por estes sons se alcança: 3 . que a sua necessidade é igual a da sociedade recíproca: 4. que sua antiguidade é coeva a nossos primeiros pais". ${ }^{23}$

Ou, como assinala Jerônimo Soares Barbosa, na Introdução de sua Gramática Filosófica da Língua Portuguesa, escrita em Coimbra, em 1803, e só publicada em 1822:

“Toda gramática é um sistema metódico de regras, que resultam das observaçôes feitas sobre os usos e fatos das línguas. Se estas regras e observaçóes tem por objeto tão somente os usos e fatos de uma língua particular, a gramática será também particular. Se elas porém abrangem os usos e fatos de todos ou da maior parte dos idiomas conhecidos, a sua gramática será geral. Uma e outra pode ser, ou somente prática e rudimentar ou filosófica e razoada. [...]

Porém se o espírito se adianta a indagar e descobrir, nas leis físicas do som e do movimento dos corpos orgânicos, o mecanismo da formação da linguagem, e nas leis psicológicas as primeiras causas e razóes dos procedimentos uniformes que todas as línguas seguem na análise e enunciação do pensamento, então o sistema que d'aqui resulta, não é já uma Gramática puramente prática, mas científica e filosófica. [...] Que por isso a gramática foi sempre reputada da lógica, pela íntima conexão que as operaçôes do nosso espírito tem com os sinais que as exprimem. E esta é a razão por que os antigos filósofos, e os estoicos principalmente se faziam cargo d'ela nos seus tratados de filosofia, como Protágoras, Platão, Aristóteles, Teodetes, Diógenes, Crisipo,

23 Cf. Bacelar 1783: 2-3. Com o mesmo título de 'gramática filosófica' temos ainda a de Couto e Melo, publicada em Lisboa, pela Impressão Régia, em 1818; e a de Jerônimo Soares Barbosa, Grammatica Philosophica da Lingua Portugueza, ou Principios de Grammatica Geral applicados á nossa linguagem, publicada em Lisboa, em 1822, pela Typographia da Real Academia das Sciencias. 
Palemon e outros, sobre os quais se pode ver Laercio nas suas vidas e Quintiliano Inst. Orat., I,6."24

Mas, nesse contexto gramatical, não podemos também esquecer a formação oratorina de Silvestre Pinheiro Ferreira e a importância de $O$ verdadeiro método de estudar, de Luís António Verney, no contexto do iluminismo português, no qual a gramática, tema da $1^{\text {a }}$ Carta dentre as 16 Cartas que compóem o método, é apresentada como "a porta dos outros estudos". ${ }^{25} \mathrm{~A}$ influência do iluminismo português, sua expressão nas 'gramáticas filosóficas' e na extensão relacional entre a "arte de falar" e a "arte de pensar", estará, marcadamente, presente nas Preleçóes Filosóficas, onde reencontraremos a classificação e a definição das palavras, apresentadas em O Patriota, e que compóem, na sequência, os seus comentários às Categorias de Aristóteles ${ }^{26}$.

Sob esse aspecto, é interessante observar, ainda, que as Preleçóes Filosóficas serão anunciadas e divulgadas, pela redação d'O Patriota, no mesmo número no qual Pinheiro Ferreira publica sua carta ao jornal explicitando as observaçóes acerca das sílabas, que havia sido apresentada de modo in-

24 Barbosa 1822: XI-XII. Para análise das gramáticas filosóficas em Portugal, veja-se Couto 2004: 11-31 e Gonçalves 2006.

25 Cf. Verney 1747: 4. Silvestre Pinheiro Ferreira ingressou na Congregação do Oratório em 1783, aos 14 anos de idade, com intenção de seguir a vida eclesiástica, e onde concluiu o curso de Humanidades. Mas, como indicam seus biógrafos, apesar de ter sido aluno de grande brilho, acabou por polemizar com Padre Teodoro de Almeida o que deu início a uma perseguição que terminou com a sua saída da Congregação e a renúncia à vida clerical, voltando-se, entáo, para o ensino leigo, tendo ministrado durante algum tempo aulas particulares de filosofia em Lisboa, até ser aprovado, por concurso, em 1794, para lente substituto na cadeira de Filosofia Racional e Moral no Colégio das Artes da Universidade de Coimbra. Em Coimbra, entretanto, Pinheiro Ferreira ficará pouco tempo, pois, em função de suas críticas a Verney e Genovesi, será mais uma vez perseguido e acusado de “jacobinismo”, fugindo para a França, em julho de 1797, a bordo de um navio holandês que deveria passar por aquele país. Todavia, seu roteiro será alterado, tendo desembarcado em Dover, e permanecido em Londres até conseguir recursos para chegar à Holanda, onde se encontrou com o futuro Conde da Barca - que terá importância capital na estada da Corte Portuguesa no Rio de Janeiro -, então Ministro de Portugal em Haia, que o acolheu. E, sob a proteção deste, foi nomeado interinamente secretário da Embaixada Portuguesa em Paris, e, em 1798, secretário da Legação Portuguesa na Holanda, tendo ainda acompanhado o Conde da Barca "em uma viagem de instrução ao Norte da Alemanha, regressando ambos a Lisboa em 1802” (Cf. Silva, 1862: 261-269 e Lima, 2006: 344).

26 Cf. Preleçôes Filosóficas, \$235-251. Se formos também conferir no "Índice não só destinado a indicar os lugares destas vinte e duas primeiras Preleçóes em que se trata das diferentes matérias, mas a dar uma idéia resumida delas e mesmo a corrigir e suprir alguns descuidos, em que se advertiu ulteriormente", encontraremos todos os termos da gramática filosófica d'O Patriota, igualmente definidos e com a indicação dos parágrafos em que são tratados. 
completo no primeiro número do jornal, isto é, sem o título de "gramática filosófica" e sem o reconhecimento de que seu autor é versado em questóes relativas à "filosofia das línguas" - agora explicitadas em termos de uma "gramática filosófica" -, portanto, a carta publicada no número 4, de abril de 1813, alarga os significados anteriores e reafirma a proximidade entre o projeto do jornal e o projeto das Preleçóes Filosóficas, e, a divulgação aí feita, parece, vem ratificar integralmente nossa hipótese: a política, tal como as sílabas, ganha 'substancialidade' nas articulaçôes de afinidade e repleção que, por sua vez, possibilitam não só os 'discursos', mas, também, a própria 'ação política', o que seria, posteriormente, ratificado pelo grande projeto exposto na 30a Preleçấo.

Assim, dizendo-se sem notícias modernas da Europa, o Redator do jornal afirmará ter a oportunidade de ocupar-se de uma notícia deveras interessante, pois, em lugar de "aterrar a humanidade, como as sanguinárias guerras, fazem o seu mais belo ornato, e concorrem diretamente a sua felicidade". Trata-se, pois, da notícia de abertura, em 1 de abril de 1813, da Academia Real Militar, com Aulas de Astronomia, Geodesia, Tática, Física e Química, proporcionando, assim, o "aumento das luzes", trazidas por "instituiçóes úteis", oferecidas à educação militar, e, depois de descrever todo o currículo que lá será estudado, o Redator do jornal informará aos seus leitores sobre as Preleçóes Filosóficas de Silvestre Pinheiro Ferreira, acrescentando:

"A este Régio estabelecimento [a Academia Real Militar] tenho a satisfaçáo de ajuntar o utilissimo Plano de Preleçôes Filosóficas de um homem de conhecido saber, e da mais bem merecida reputação. É escusado pronunciar sobre a sua utilidade, quando sobra a sua mesma exposição. Além da manifesta necessidade das matérias, que se vão explicar, brilha no Plano que se segue aquele espírito de método que é só produzido por uma madura meditação sobre as matérias, que tem já feito o objeto de um sério e acurado estudo.

O Curso de Preleções Filosóficas terá por objeto:

$1^{\circ}$ A Teórica do Discurso e da Linguagem: em que se exporão os Princípios da Lógica, da Gramática geral, e da Retórica.

$2^{\circ} \mathrm{O}$ Tratado das Paixóes: primeiramente consideradas como simples sensaçôes, e versando sobre matérias de Gosto; donde se deduzirão as regras da Estética, ou da Teórica da Eloquência, da Poesia, e das Belas Artes: depois consideradas, como atos morais, compreendidos nas ideias de Virtude ou de Vício, darão lugar a desenvolverem-se as maximas da Diceósina, que abrangerá a Ética e o Direito Natural. 
$3^{\circ} \mathrm{O}$ Sistema do Mundo: em que depois de se tratar das propriedades gerais dos Entes, ou da Ontologia, e da Nomenclatura das Ciências físicas e matemáticas, se expenderão as noçóes elementares da Cosmologia: e destas se deduzirão as relações Entes criados com o Criador, ou os Principios da Teologia Natural.

Além da Exposição de Teórica, haverá em cada uma das Preleçóes lição e análise de alguma Obra escolhida dos principais Filósofos, Oradores e Poetas, assim antigos como modernos, sagrados e profanos.

No dia 26 do corrente recitou o Sábio Professor um eloquente discurso sobre as matérias acima enunciadas, onde brilharam os princípios filosóficos que o distinguem, e prorrogou as suas Preleçôes para o dia 18 de Maio." (S1, 4, IV, 92-93, 1813, grifos nossos).

Visto sob essa ótica, não parece difícil inferir que temos claramente articuladas as 'categorias' da língua que irão gerir o que será definido nas Preleçôes Filosóficas, como a "arte de falar" e sua conjugação imediata com a "arte de pensar" 27, aí incluídas a tradução e a análise das obras de diferentes autores, como 'procedimento filosófico' que também compóe o aprendizado e o exercício da "arte de falar" com a "arte de pensar". Ora, se nos voltarmos, rapidamente, para o outro texto de Silvestre Pinheiro Ferreira, publicado no volume 1 da Segunda Subscrição d'O Patriota, em julho de 1813, "Memória sobre um novo princípio da Teórica do Calórico", veremos que "a arte de pensar" será exemplificada com um 'caso científico', e que, tal como as 'categorias' que sustentam a língua que compóe a "arte de falar", elucidam, também, as teses apresentadas na "Introdução" do primeiro número do jornal.

Nesse sentido, ao escolher o fenômeno da "explosão da pólvora", Silvestre Pinheiro Ferreira afirma que quando um fenômeno, apesar de todos os esforços, não pode ser reduzido a nenhum dos princípios constitutivos da Teórica da Ciência a qual ele pertence, pois isto implicaria na inferência de que a Teoria, mesmo não sendo falsa, "é defeituosa em seus princípios", e ainda que, se este fenômeno não puder ser reduzido a nenhum dos princípios de sua teórica, ou mesmo mostrar-se contrário a alguns desses princípios, pois isto significaria que este "princípio ou é hipotético ou tem sido demasiadamente generalizado", fica demonstrado que o fenômeno da explosão da pólvora é, exatamente, o princípio mais importante na "teórica do calórico":

\footnotetext{
27 Cf. Preleçōes Filosóficas, $\$ 1-8$.
} 


\begin{abstract}
"[...] se observarmos que na explosão da pólvora há desenvolvimento de calórico, entretanto que os elementos da mesma pólvora passam do estado de solidez, em que se achavam, ao estado gasoso, mediante a explosão. É verdade que o imortal Lavoisier, tendo em vista este mesmo fenômeno, supos que o ácido azótico [o ácido nítrico] fixando-se na sua combinação com a potassa, para a formação do nitro (um dos princípios ingredientes da pólvora) conserva a maior parte do calórico, que continha no seu precedente estado gasoso.

Mas esta suposição de Lavoisier, além de não ser fundada em nenhum outro fato, senão aquele mesmo que por ele se pretende explicar, é incompatível com a Téorica, tal como ela nos tem sido ensinada até o presente." (S2, 1, VII, 3-4, 1813).
\end{abstract}

Mas, a questáo comporta, ainda segundo Pinheiro Ferreira, o problema relativo à compreensão do "princípio" na passagem do ácido sólido ao gasoso na explosáo da pólvora, pois, tal como posto por Lavoisier - "há desenvolvimento do calórico, e que os elementos da mesma pólvora (corpo sólido) passando do estado de solidez em que se encontravam, para o estado gasoso" com a explosão -, não soluciona o problema, pois, "não só não tomam dos corpos ambientes calórico, fazendo com que eles esfriem; mas antes perdem uma tão considerável porção dele, que se manifesta na calorificação excessiva de tudo o que os cerca até uma notável distância". Daí, a tentativa silvestriana de tornar o "fenômeno da explosão da pólvora" compatível com os princípios da conhecida e "aliás incontestável teórica do calórico" (S2, 1, VII, 4-5, 1813).

Para fazer tal demonstração, Silvestre Pinheiro Ferreira partirá da 'teoria da definição’ que, nessa altura, julho de 1813 , já fora exposta nas suas Preleçóes Filosóficas, iniciadas em 26 de abril, como sendo parte do processo de 'entendimento' entre um homem que fala e outro que escuta, o que suscita ideias no ânimo de cada um deles, e, quanto maior forem as ideias comuns, maior será o entendimento que se faz ao se dizer o que se entende por uma determinada expressão que é desconhecida: "diz-lhe, refere-lhe, enumera-lhe as ideias que nele mesmo costuma suscitar aquela expressão, quando a ouve em semelhantes circunstâncias", este expediente, dirá Silvestre Pinheiro Ferreira, "chama-se definir", e, por isso, poderá concluir em seguida: "definir uma expressão é, enumerar as ideias comuns, que ela costuma suscitar em todos os que dela se servem em semelhante caso ${ }^{28}{ }^{28}$ E que, conforme é exposta em nota de rodapé ao texto de sua Memória, consiste

\footnotetext{
28 Cf. Preleçôes Filosóficas, \$34-35.
} 
no processo de enumerar ideias, despertadas "no ânimo de todos que delas se servem", sendo, portanto, necessário para definirmos uma palavra, "analisar o que se passa no espírito daqueles que dela se servem", donde podemos, ainda, inferir que "para uma mesma expressão, se podem fazer muitas análises; muitas podem ser as definiçóes: cada uma mais ou menos perfeita, segundo que a análise for mais ou menos bem feita" (S2, 1, VII, 5, 1813).

Desse modo, o calórico será, então, definido como algo que é entendido por "todos os químicos", como "uma substância, cujas partes exercitam todas, umas sobre as outras, uma repulsão indefinida", e donde devemos "deduzir todos os princípios, tanto os já conhecidos como os adicionais", que ele pensava faltarem à Teórica do Calórico, e "como todos concordam que o calórico dilata os corpos", este é o sentido da definição. E remetendo a nota de rodapé (1), na página 5 , àqueles químicos que negam ser o calórico uma substância, Pinheiro Ferreira, afirmará, ainda,

"Poderia parecer que desta generalidade deveriam exceptuar-se aqueles Químicos, que negam a existência de uma substância, a que só haja de dar o nome de Calórico: e na sua opiniáo esta palavra, bem como na opinião de todos a palavra atração, nada mais significa, do que um simples fato; isto é a dilatação dos corpos, que se dizem calefatos. Seria impróprio deste lugar o fazer ver que semelhante discrepância deriva unicamente da errada definição, que vulgarmente corre da palavra substância, pois que partindo da verdadeira definição, desaparecem, tanto esta, quanto inúmeras outras questôes, sobre serem as coisas, de que se trata, substâncias ou meras quantidades. Em umas Preleçôes Filosóficas, que faço atualmente imprimir, trato circunstanciadamente esta matéria" (S2, 1, VII, 5-6, 1813).

Portanto, admitindo-se tal definição, os corpos, na medida em que se aproximam do mínimo da "afinidade de agregação, se aproximarão igualmente da afinidade de combinação", donde, concluirá Pinheiro Ferreira que a primeira consequência derivada da definição dada é que "uma substância deve possuir a máxima afinidade de combinação para com todos e quaisquer corpos que se acharem em sua esfera de atividade" (S2, 1, VII, 6, 1813).

Por outro lado, se considerarmos que a afinidade de agregação das partes de um corpo entre si difere da que existe entre as partes de outro corpo, "segue-se que a afinidade de combinaçáo do calórico deve ser diferente para os diferentes corpos", e, independentemente de sua combinação com qualquer corpo, a força repulsiva das partes do mesmo calórico entre si há de ser aniquilada no todo ou em parte pela força de atração que existe entre as partes do corpo, com o qual 
ele estiver combinado. Se cada uma das partes de um corpo está reunida a todas as outras pela força da atração, essa "deve crescer na razão direta do número das partes componentes", donde segue-se que a soma das forças atrativas em um número qualquer de partes é menor quando elas estão separadas do que quando estavam unidas, pois, "que depois de separadas não existem senão as forças, que reúnem partículas de segunda ordem”, enquanto, quando estão juntas, existem também as partes que destas se compóem e se exercitam entre si.

Assim, quanto maior for uma força atrativa, tanto maior será a força repulsiva, que com ela terá de equilibrar-se, logo, dirá Silvestre Pinheiro Ferreira, "se as partes de um corpo reunidas tem maior soma de forças atrativas, do que separadas, hão de poder aniquilar no seu estado de reunião uma maior soma de forças repulsivas, ou háo de precisar de uma maior quantidade de Calórico para a sua saturação, do que estando separadas". A conclusão silvestriana será, entáo, a de que, quando as partes de um corpo se separam:

"[...] uma porção de Calórico, até agora retida pela força de atração, que perece pela simples fratura do corpo, obedecerá à força repulsiva das outras partes do mesmo Calórico, que ainda ficam combinadas com o corpo; e por conseguinte a aquecer todos os corpos ambientes. Não é pois unicamente pela solidificação que se desenvolve Calórico livre, como até ao presente se tem ensinado. Há, além deste, outro princípio de desenvolvimento de Calórico, que é a pulverização, como acabo de demonstrar.

Façamos aplicação deste novo princípio ao fenômeno da explosáo da pólvora, de que falamos ao princípio desta Memória" (S2, 1, VII, 7-8, 1813).

Ora, se nos voltássemos agora para o projeto d'O Patriota apresentado na Introdução do primeiro número, de janeiro de 1813, citado anteriormente, poderíamos confirmar que o autor desse texto mesclou muito habilmente, e de modo muito próximo às teses apresentadas por Pinheiro Ferreira publicadas em diferentes subscriçôes do próprio jornal, a "invenção das letras" com o "progresso das Ciências e das Artes”; a ação 'calórica' dos raios de sol que "dispersos aquecem os corpos duros, juntos em um foco derretem os mais duros metais"; a proposta dos sábios de "lançarem reciprocamente suas luzes para que da união delas resultasse aquele intenso calor, que vencesse a frieza da preguiça e a dureza da ignorância", ao projeto (contrário ao que havia sido o projeto primeiro, e, de certo modo, precário e fracassado, de colonização do Brasil) de 'politizaçáo' de uma 'terra', agora entendida como 'pátria', e outrora precariamente colonizada, e que, para não se perder, deve- 
ria assumir sua condição política, seja com a criação de um novo princípio de cidadania e de uma nova 'forma constitucional' capaz de garantir essas mudanças a partir de um programa 'filosoficamente' estruturado:

"Assim depois de vos ter dado em outras partes as definiçóes do Bom e do Mau: do Justo e do Injusto: do vício e da virtude, farei da Diceosina, ou do Tratado dos Direitos e Deveres do Homem e do Cidadáo, dos Estados e das Sociedades, o objeto de uma série de Preleçôes, que se bem serão interpoladas com outras de diferente assunto, formaráo entre si um corpo seguido de doutrina, que corresponderá, senáo no desempenho, ao menos no seguimento, aos desejos, que me haveis testemunhado." ${ }^{29}$

Ou seja, um projeto de nação cujo suporte seria o 'processo' no qual a literatura (no sentido largo a ela atribuído no século XIX) e a ciência produziriam a base substancial da ideia de nação, acrescida de um adjetivo que apontava para o tópos pátrio, isto é, para o solo que deverá ser chamado de 'brasileiro'.

Assim, ao retomar a tese de Lavoisier sobre o calórico, a intenção de Pinheiro Ferreira será: [i] explicitar um procedimento 'metódico' que já está sendo utilizado em suas Preleçóes Filosóficas, [ii] demonstrar como alguns impasses da "Teórica das Ciências" podem ser superados a partir da "Teoria da definição", que, igualmente, está sendo exposta em suas Preleçôes, e afirmar que, [iii], as condiçôes [i] e [ii] estão, por sua vez, articuladas com a "correta" definição de 'substância'30 (Cf. S2, 1, I, 3-7, 1813), e que, interpretadas à luz das Categorias

29 Cf. Preleçōes Filosóficas, $\$ 976$.

30 Para a discussão acerca do problema da 'substância', veja-se Preleçôes Filosóficas, $\$ 43$, \$71-106, onde na base da discussão silvestriana estará a tradução de oủ oía por "essência” e não por 'substância', no passo 2a11, das Categorias de Aristóteles, tal como na tradução latina aposta ao texto grego na edição de Isaac Casaubon, utilizada por Silvestre Pinheiro Ferreira em sua

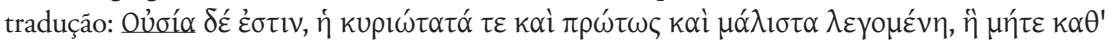

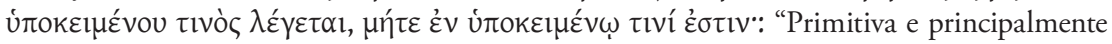
chama-se essência primária àquela, que nem se diz de nenhum objeto, nem está em nenhum objeto." (Cf. Aristóteles 1814: A.15; E.15, grifos nossos. A referência à tradução das Categorias será feita de acordo com a edição de Pinheiro Ferreira, que, propondo uma numeração própria, divide o texto em duas classes numeradas, os Aforismos e as Explicaçóes, aqui indicadas por A. e o número dado ao Aforismo, e, pelo E. e o número dado à Explicação). Talvez por isso tenha Pinheiro Ferreira, no $\$ 80$ das Preleçóes Filosóficas, chamado a atenção de seus leitores para a "extraordinária e perniciosa confusão que os Filósofos têm feito das palavras que acabamos de definir: e por essa razão julgo dever fixar mais no vosso espírito as verdadeiras noçóes delas, confrontando debaixo de um só golpe de vista o conteúdo destes últimos três parágrafos. Devemos portanto não perder jamais de vista, que a palavra corpo designa a reunião de algumas, ou de todas as qualidades referidas no $\$ .43$, ou sós, ou juntas a algumas outras, segundo o caso 
de Aristóteles, como veremos em seguida, são as chaves interlocutórias das Preleçôes Filosóficas, cujas 'luzes' atingirão, também, o modelo a partir do qual Pinheiro Ferreira irá estruturar o projeto político apresentado a D. João VI, em suas Memórias Politicas sobre os Abusos Gerais e Modo de os Reformar e Prevenir a Revolução Popular redigidas por Ordem do Principe Regente no Rio de Janeiro em 1814 e 1815, e dará a medida do modo como uma "naçáo se civiliza", ou seja, o modelo que os portugueses deveriam seguir na construção do Império do Brasil - antes que "este nascente Império do Brasil" que "já luta com as ânsias de uma infalível morte, se a mão de $\mathrm{V}$. A. R., por alguns poucos instantes poderosa, não acode a salvá-lo" 31 -, ou aquele modo ao qual os 'brasileiros' deveriam ter em conta, a partir de 1822, para construírem o seu 'Império do Brasil'. Portanto, o que pretendemos mostrar, já nessa primeira versão do pensamento de Pinheiro Ferreira, exposto no Brasil em suas Preleçóes Filosóficas e em O Patriota, é que a presença do pensamento antigo não se configura apenas como uma "legitimação de autoridade como sinal de controle de uma certa erudição"32, e, também, como "emulação para o presente com vistas ao futuro"33 , mas, como o esforço de pensar a 'gênese de uma nação' (ou, para usarmos o 'vocabulário' caro ao jornal, de uma 'pátria') e de alicerçar esse nascimento em uma forma de pensamento já estabelecida na tradiçấo ocidental: o pensamento grego. A originalidade da leitura e da interpretaçáo do pensamento antigo proposta por Pinheiro Ferreira está, acreditamos, no fato dessa hermenêutica tentar afastar-se das leituras religiosas - seja ela, a dos jesuítas ou dos oratorianos e que lhe foram contemporâneas -, buscando dela extrair uma nova compreensão para uma nova temporalidade (a migração da Corte portuguesa para o Brasil e as mudanças políticas daí advindas), sem entretanto, deconectar tal interpretação de suas raízes onde reside o fundamento do seu modo de ser e justifica o processo de 'transmigração de ideias' na construção da vida política.

de que se trata. Já por substância entende-se somente o complexo daquelas qualidades que se observam em qualquer estado possível. Por essência, porém unicamente o complexo daquelas qualidades atuais, a quem compete o epíteto de essenciais" (\$.72). Cf. também o comentário acerca das definições de 'essência' e 'substância', em Aristóteles, na 29ã Preleção.

31 Ferreira 1814(a).

32 Cf. Guimarães 2007: 75.

33 Idem, ibidem. 


\subsection{As Preleçóes Filosóficas e o modo como as naçóes se civilizam}

No ambiente eclesiástico no qual a filosofia foi sempre ensinada no Brasil Colônia ${ }^{34}$, as Preleçóes Filosóficas, de Silvestre Pinheiro Ferreira, são, efetivamente, uma conquista advinda da chegada da família real no Rio de Janeiro, em 1808, e que, acreditamos, deve ser, em primeiro lugar, compreendida no âmbito das mudanças introduzidas por D. João VI, e, dentre elas, a formação de uma Biblioteca Pública, a instauração das escolas profissionais - a Escola de Medicina, na Bahia, e a Escola Médico-Cirúrgica, no Rio de Janeiro -, a Real Academia Militar, o Horto Botânico, a Academia de Belas Artes, o Museu Nacional, a Aula Régia de Economia, o projeto do Instituto Acadêmico, e a instalação da Imprensão Régia que começa a funcionar ainda em 1808, portanto, em meio ao processo de montagem do Estado que daria ao Brasil o estatuto político de Reino, para, alguns anos mais à frente, estruturar as bases de um Império.

As Preleçôes Filosóficas foram proferidas no Real Colégio de São Joaquim, ${ }^{35} \mathrm{e}$, embora as datas de início e fim não tenham sido claramente definidas pelos historiadores, temos notícia, pelo anúncio publicado na Gazeta do Rio de Janeiro, de 13 de abril de 1813, do programa e do seu início no dia 26 de abril, acrescentando-se, ainda, que aqueles que "quiserem subscrever para estas Preleçôes, que serão nas segundas, quartas e sextas feiras pelas 5 horas da tarde, dirigir-se-âo ao Reverendo Reitor do mesmo Colégio de S. Joaquim", e que a "subscrição é de meia dobla ao mês"; bem como, a informação veiculada por $O$ Patriota, na S1,4,IV,92-93,1813, de que no dia 26 de abril Pinheiro Ferreira teria feito sua primeira Preleção, e que as teria prorrogado até o dia 18 de maio: "No dia 26 do corrente recitou o Sábio Professor um eloquente discurso sobre as matérias acima enunciadas, onde

34 Antes da vinda de D. João VI, e após a expulsão dos jesuítas pelo Marquês de Pombal, em 1759, o estudo da filosofia entre nós ficaria quase inteiramente restrito aos Seminários, que nem sempre adequaram seu ensino às normas pombalinas; e as denúncias feitas pelos Professores Régios nomeados parecem sublinhar a influência do ensino religioso, quando relatam que ensinavam ao público a filosofia proscrita pela reforma, "em umas apostilas peripatéticas cheias de questôes escuras e inúteis que servem de arruinar e fazer perder o gosto aos bons estudos". Apud Sucupira 1976: 360. Cf. também a polêmica entre os professores régios de latim nomeados para Pernambuco apresentada no Apêndice do livro de Laerte Ramos de Carvalho, As reformas pombalinas da instrução pública, 1978: 193-229.

35 Que se transformaria posteriormente no Colégio Pedro II. 
brilharam os princípios filosóficos que o distinguem, e prorrogou as suas Preleçôes para o dia 18 de Maio".

Quanto ao seu término, as datas são também controversas, mas é quase certo que tenham se prolongado, no mínimo, até o final de 1815, como sugere Antonio Paim, na introdução da edição por ele organizada das Preleçôes Filosóficas ${ }^{36}$, ou como podemos inferir, a partir da informação que nos é dada por Luis Joaquim dos Santos Marrocos, em Carta de 23 de fevereiro de 1816, onde em uma de suas caústicas referências a Pinheiro Ferreira afirma:

\begin{abstract}
"Silvestre Pinheiro, no tempo em que esteve suspenso de seus lugares, ocupou-se em ensinar Filosofia por um método mui amplo e générico, que abrangia todos os seus ramos: julgo que suas intençôes lhe sairam difíceis na prática, do que havia concebido, porque enfim são proposições à Francesa. Tem publicado alguns folhetos de suas Preleções e não sei se ainda continuará, de cuja Coleção remeterei a V. M. um exemplar, como me recomenda; e na introdução se conhece a verdade do que digo acima." ${ }^{37}$
\end{abstract}

Se for correto o que diz Marrocos, as Preleçóes teriam sido ministradas até 1815, quando Pinheiro Ferreira passa a integrar a Direção da Real Tipografia.

Quanto a sua publicação em fascículos, pela Impressão Régia, no Rio de Janeiro, a partir de 1813, a carta de Marrocos parece também confirmar, bem como, a mesma Gazeta do Rio de Janeiro, em 28 de agosto de 1813, noticia a publicação da Primeira Preleção, que poderia ser comprada por $200 \$ 00$, na loja da Gazeta e na de Francisco Luiz Saturnino. Uma outra indicação que nos permite inferir a publicação seriada está na "Advertência"

\footnotetext{
36 Cf. Paim 1970: 7.

37 Luis Joaquim dos Santos Marrocos chegou ao Rio de Janeiro em 1811, juntamente com a segunda remessa dos livros da Real Biblioteca. Em Lisboa, havia servido como ajudante das Reais Bibliotecas, desde 1802, e, no Rio de Janeiro, serviu na Real Biblioteca, trabalhando junto ao Padre Joaquim Damásio e, em setembro de 1811, foi nomeado pelo Princípe Regente responsável pelo "arranjamento e conservaçáo dos Manuscritos da Coroa, que S. A. R. determinava permanecessem junto à sua pessoa, e dos mais papéis que ordenasse para o futuro" (Garcia 1934: 9). Suas cartas à família, escritas entre 1811-1821, estão arquivadas na Biblioteca da Ajuda, em Lisboa, e foram editadas por Rodolfo Garcia, nos Anais da Biblioteca Nacional do Rio de Janeiro, v. 56, de 1934, a partir de cópias autênticas, obtidas pela intervenção de Luiz Edmundo. As cartas também foram parcialmente reeditadas nos Cadernos da Biblioteca Nacional, v. 4, com o título O Bibliotecário do Rei - Trechos selecionados das cartas de Luis Joaquim do Santos Marrocos, no Rio de Janeiro, em 2007. Cf. Carta 98, da edição de Rodolfo Garcia, 1934: 266-267. Os grifos são nossos.
} 


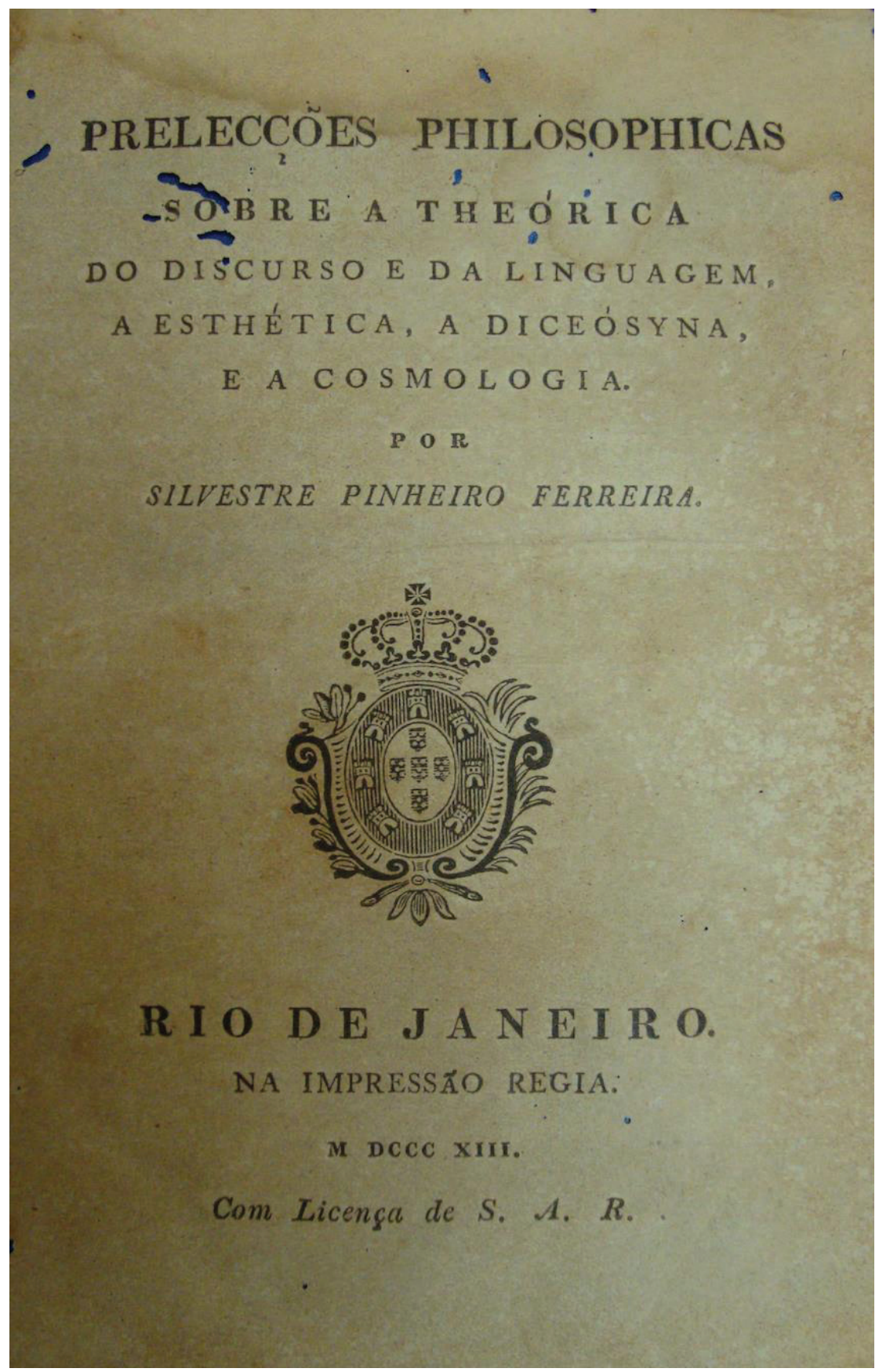

Folha-de-rosto das Preleçôes Filosóficas (Acervo da Fundação Biblioteca Nacional, Rio de Janeiro) 
que aparece logo após a folha de rosto da tradução das Categorias: "Uma das partes mais essenciais do Curso de Preleçōes Filosóficas, que estou atualmente publicando...”. Ou, ainda, a nota em O Patriota, S2, 3, IX, 1813, anunciando as obras publicadas, em agosto de 1813, na Corte, nos fala da publicação das Preleçôes Filosóficas, e, pelo resumo ali apresentado, parece referir-se à publicação da $1^{a}$ Preleção:

"Obras publicadas nesta Corte no mês de Agosto.

Preleçóes Filosóficas sobre a teórica do Discurso e da Linguagem, a Estética, a Diceósina e a Cosmologia. Por Silvestre Pinheiro Ferreira.

O A., cujos talentos são tão justamente acreditados, dá primeiro uma ideia geral da Obra, reduzindo a três objetos das suas Preleçóes, a saber, a teórica do Discurso e Linguagem, o tratado das paixóes, e o sitema do Mundo: no $1^{\circ}$ expóe os princípios da Lógica, da Gramática Geral e da Retórica; no $2^{\circ}$ considera as paixôes ou como simples sensações, ou como atos morais: da primeira consideração nascem a Estética, a Poesia, e as Belas Artes, e a segunda produz a Diceósina: debaixo da denominação da Cosmologia, involve a Ontologia, e a nomenclatura das Ciências matemáticas e físicas, e daí deduz os princípios da Teologia Natural." (S2, 3, IX,79, 1813)

Por outro lado, o Correio Braziliense, de Hipólito da Costa, informa, no exemplar de outubro de 1814, o aparecimento das oito primeiras Preleçóes, e, no número de agosto de 1816, informa aos seus leitores as publicaçôes da Nona à Vigésima Preleção ${ }^{38}$. Parece, então, razoável a indicação de Rodolfo Garcia, na nota 45 de sua edição das Cartas de Marrocos, de que a publicação da obra foi iniciada em 1813, que em 1816 apareceu a 23a Preleção, em 1818 da $26^{a}$ à $29^{a}$ Preleção, e, em 1820, a 30a Preleção, que foi a última a ser impressa. ${ }^{39}$ A versão hoje conhecida das Preleçóes Filosóficas, em um único volume, com a folha-de-rosto indicando 1813 como ano de publicação, provavelmente deve ser o resultado da encadernação de todos os fascículos "capeados" pela folha de rosto publicada com o primeiro fascículo, com o Índice das Vinte e duas

38 As críticas que Hipólito da Costa fará às Preleçôes serão refutadas por Silvestre Pinheiro Ferreira na Décima Oitava Preleção, a partir do $\$ 590$, o que nos permite supor que só devem ter sido redigidas no final de 1814. Observamos, entretanto, que esta informação publicada pelo Correio Brasiliense, em agosto de 1816, nos permite indagar se o curso náo se prolongou para além de 1815 .

39

Cf. Garcia 1934: 267. 
primeiras Preleções, com a indicação de Tomo I, Parte I, acrescida de um Suplemento, com paginação própria, o Índice contido nas páginas 1 até à 89, e o Suplemento, nas páginas 90 até à $101 .{ }^{40}$

Ora, se seguirmos as indicaçóes publicadas em abril de 1813, na primeira subscrição de $O$ Patriota, como citado anteriormente, e, se nos ativermos às "Advertências" do autor, contidas na sequência das folhas-de-rosto das Preleçóes Filosóficas e da tradução das Categorias, veremos que seu projeto, além de educativo e filosófico, contém, claramente demarcada, uma estratégia política, delimitadora de um Estado e de uma nação, que deve estar subscrita na tradição do pensamento antigo, e, sob essa ótica a escolha do texto aristotélico pode ser lida em múltiplas dimensôes: da crítica aos jesuítas e, de certo modo, aos oratorianos - sublinhando aí a redefinição da tradição aristotélica portuguesa -, à crítica a Arnault e à escola de Port-Royal em suas

40 A Biblioteca Nacional do Rio de Janeiro possui parte da edição em fascículos, e uma edição quase completa, faltando apenas a 30a Preleção, mas contendo o Índice e o Suplemento ao Índice, e encadernada juntamente com as Preleçôes Filosóficas, encontramos a edição de 1814, pela Impressão Régia, da tradução de Pinheiro Ferreira das Categorias de Aristóteles (cf. FBN - 37,0,5,N1 e FBN - 37,0,5,N2), pertencente à Coleção Benedito Ottoni, que é composta pela biblioteca de José Carlos Rodrigues, colecionador e bibliófilo que, ao ser posta à venda, foi adquirida por Júlio Benedito Ottoni, que a doou integralmente à Biblioteca Nacional, e, em 1911, foi incluída no acervo da FBN. Como podemos observar nos fascículos pertencentes à $\mathrm{FBN}$, a paginação dos fascículos foi progressiva, daí sua aparente natural integração em um único volume. $\mathrm{O}$ fascículo referente à $7^{a}$ Preleção, no acervo da FBN, tem início na página 73 e fim na página 90, com carimbo da Real Biblioteca nas páginas 75 e 90, o que significaria, segundo informação da Profa. Ana Virgínia Pinheiro, Chefe da Seção de Obras Raras, da FBN, o início da obra (com o carimbo da Real Biblioteca no primeiro espaço em branco depois da folha-de-rosto) e o seu fim, com o carimbo no final do texto. Portanto, parece muito provável que os fascículos assim paginados tenham sido encadernados em uma única obra, tal como podemos consultar no acervo da Biblioteca Geral da Universidade de Coimbra, e no exemplar pertencente à Coleção D. Carolina Michaelis de Vasconcelos, do Instituto de Estudos Românicos, da Faculdade de Letras da Universidade de Coimbra, na qual a edição das Categorias está também encadernada em conjunto com as Preleçôes. Vale observar, ainda, que o Real Gabinete Português de Leitura, no Rio de Janeiro, possui as nove primeiras Preleçôes, com paginação progressiva e que no final da obra de Silvestre Pinheiro Ferreira, Noçóes elementares de Filosofia geral e aplicada as ciências morais e politicas: ontologia, psicologia, ideologia, publicada em Paris, em 1839, também pertencente ao acervo do Real Gabinete, encontramos, na enumeração das obras do autor, a indicação das Preleçôes Filosóficas, impressas no Rio de Janeiro, em 1813, 1 v. $4^{\circ}, 5$ fr., que também nos sugere a posterior encadernação dos fascículos com a folha-de-rosto do primeiro fascículo impresso em 1813. Outro dado que parece, também, confirmar tal sugestão é a observação manuscrita por Joaquim Vasconcelos na folha-de-rosto do exemplar da Coleçáo Carolina Michaelis de Vasconcelos: "Ediçôes raras que de modo nenhum se devam emprestar". O plural tanto pode valer para a conjunção das Preleçōes Filosóficas com a tradução das Categorias, quanto para o conjunto dos fascículos, e, ainda, para ambos. 
objeçóes ao autor das Categorias, e mesmo ao pensamento que lhe é contemporâneo, na segunda metade do século XVIII (na crítica a Condillac e Desttut de Tracy, por exemplo) e na primeira metade do século XIX. Dessas críticas, nasce, acreditamos, uma leitura muito arguta do pensamento antigo, que continuará presente no processo de independência do Brasil, sobretudo no modelo político-constitucional pensado por José Bonifácio de Andrada e Silva, e que, com novas modalidades, reapareceria no governo de D.Pedro II.

A estruturação das Preleçóes pretende, assim, abarcar o domínio que Pinheiro Ferreira compreende como o da Filosofia - entendida por ele como sendo o estudo dos "fatos comuns a todas as Ciências" ${ }^{\text {"ł1 }}$ - e de sua disposição na ordem do pensamento, observada em um contexto metódico, delimitado pelo autor na forma que se segue: [i] a teórica do discurso e da linguagem, onde serão expostos os princípios que regem a Lógica, a Gramática e a Retórica, como base do processo inteligível; [ii] o tratado das paixôes consideradas primeiro como sensaçóes, para em seguida tratar das questóes relativas ao "gosto", daí determinando as regras da estética, da retórica, da poesia e das belas artes, que, compreendidas como "atos morais", exigem a compreensão das ideias de virtude e vício, donde serão inferidas "as máximas da Diceósina, que abrangerá a Ética e o Direito Natural”; e [iii] a cosmologia, o sistema do mundo, onde tratar-se-á das propriedades gerais dos entes, da nomenclatura das ciências físicas e matemáticas, e dos princípios da teologia natural.

O autor esclarecerá ainda, na apresentação da "Idéia Geral da Obra", que, uma vez estabelecidos os necessários princípios preliminares da Teórica - o que será feito nas oito primeiras Preleçóes -, as duas outras partes mencionadas acima serão acompanhadas pela análise de "alguma obra escolhida dos principais Filósofos, Oradores e Poetas, assim antigos, como modernos, sagrados, e profanos". ${ }^{42}$

A partir da 9a Preleção Silvestre Pinheiro Ferreira começará, então, seus comentários às Categorias, de Aristóteles, procurando, simultaneamente, demonstrar o que há de semelhante e o que há de diferente no que tange à matéria filosófica, entre sua concepção da filosofia e a daqueles "escritores que o precederam, começando pelos antigos até os modernos". ${ }^{43}$

41 Cf. Preleçôes Filosóficas, $\$$ 20: "Eu disse que há fatos comuns a todas as Ciências, e que estes são do alcance da Filosofia. Isto me conduz a observar que as Ciências ou têm por objeto as faculdades do Espírito, ou as propriedades dos Corpos."

42 Preleçōes Filosóficas, f.1, 1813.

43 Cf. Preleçóes Filosóficas, $\$ 310$. 
O comentário ao texto de Aristóteles estender-se-á até à 29a Preleção, para, então, na 30a Preleçâo, dar início à discussão acerca da questão da ideia do Bom e do Mau, onde o autor descreverá o modo "como as naçóes se civilizam e avançam em bom gosto, podendo ao mesmo tempo crescer em forças e riqueza ou decair em desfalecimento e pobreza", e nesse contexto, mostrará, ainda, como as relaçóes políticas entre as naçóes devem se estabelecer em níveis de amizade e de comércio, delimitando os modos como essas relaçôes devem se conformar. ${ }^{44}$

Nesse sentido, tanto o tratado das paixóes, quanto o sistema de mundo terâo de ser pensados à luz da teórica do discurso e da linguagem, e se a "arte de pensar" e a "arte de falar" sáo indissociáveis, uma vez que,

"Todo homem, qualquer que seja o seu estado e profissáo, precisa de saber discorrer com acerto e falar com correção. Todos precisam de conhecer o Mundo, tanto o físico como o moral, de que fazem parte, isto é, as Leis gerais dos corpos, que compõem o Sistema do Mundo; e os Deveres que cada um de nós, considerado como homem e como cidadão, tem para consigo mesmo para com a sociedade, e para com o Ente Supremo, de quem havemos recebido a existência". ${ }^{45}$

os verdadeiros filósofos assentam suas doutrinas sobre a compreensão de que a "teórica do raciocínio e a do discurso é inseparável da teórica da linguagem". 46

O 'método' aí empregado envolve, assim, um primeiro conjunto de definiçôes, a sua clarificação na análise do texto filosófico - no caso, as Categorias, de Aristóteles -, e a estratégia de sua aplicação aos diversos níveis da reflexão filosófica de tal modo que possamos compreender a filo-

\footnotetext{
44 Preleçôes Filosóficas, $\$ 985$ e seguintes.

45 Preleçōes Filosóficas, $\$ 1$.

46 Cf. Preleçóes Filosóficas, $\$ 5$ e $\$ 8$, onde já criticando tanto a escolástica dos jesuítas - que na Ratio Studiorum negavam à retórica o estatuto filosófico -, quanto a crítica a Aristóteles da escola de Port-Royal, Pinheiro Ferreira afirma: "Houve um tempo em que os Filósofos julgaram que assim como dos vestidos, com que nos cobrimos, o que os corta e cose, nada cura de saber como se tecem e urdem; [...] do mesmo modo cumpria que aquele que ensinasse a Arte de pensar, ou a Lógica, se não intrometesse com as regras da Arte de falar, quero dizer da Gramática Geral e da Retórica. Donde resultou que estas duas últimas Ciências repudiadas pelos Filósofos, como que também da sua parte prescindiram da Filosofia; de modo que contentes com saberem o que haviam os Mestres mais acreditados (que nem sempre foram os mais sensatos) os Gramáticos e os Retóricos, pela maior parte, reputavam estranho à sua profissão o exame filosófico dos princípios da Arte que ensinavam.”
} 
sofia como uma espécie de "gramática universal", que nos permite o conhecimento dos princípios das ciências. Valendo, ainda, acrescentar que a essa disposição metódica o autor impóe uma apresentação didática e racional, na qual cada uma das trinta preleçóes está ordenada em parágrafos, apresentados em numeração progressiva e antecedidos todos pelo item "Assunto", em cada uma delas, onde encontra-se explicitado o seu tema, o seu assunto.

Entretanto, se também levarmos em conta as palavras contidas nas "Advertências" que o autor faz aos seus leitores e ouvintes, após a folha-de-rosto da $1^{a}$ Preleção, veremos que essa disposição metódica parece estar incluída em um contexto que prenuncia seu projeto político de conformação de um 'novo estado', uma nova 'ordem política', ou talvez, já pudéssemos sugerir, de um novo império, o "império do Brasil”, que terá sua conformação concluída anos mais tarde, em uma clara continuação da 30a Preleção, nas obras Observaçôes sobre a Constituição do Império do Brasil e sobre a Carta Constitucional do Reino de Portugal, e, no Manual do Cidadão em um Governo Representativo.

Ora, se o exercício da filosofia está, para Silvestre Pinheiro Ferreira, entre os "azares da fortuna" - que marca o tópos político no qual ela se realiza -, e os "reveses da ventura" - que a filosofia como "profissão" e "constância sobranceira" acarretou ao longo de sua vida -, como justificativa de sua proposta das Preleçóes Filosóficas,

"Azares da fortuna, cuja relaçáo pertence a outro lugar, me levaram a consagrar à instruçâo da Mocidade os momentos desocupados dos deveres próprios do Emprego, que exercito no serviço do Estado.

Era natural, que tendo de recorrer no último quartel da vida à mesma honrosa Profissão, com que nos anos da juventude abri a minha carreira no mundo literário, me valesse daquela Ciência, a quem devi sustentaçáo, amigos, e constância sobranceira e todos os reveses da ventura. Resolvi-me pois a anunciar nesta Corte um Curso de Preleçôes Filosóficas sobre a Teórica do Discurso e da Linguagem, a Estética, a Diceósina e a Cosmologia., ${ }^{\prime 7}$

as dificuldades para a execução dessa tarefa implicam na elaboração de um "Livro elementar" que pudesse "fixar" e "recordar" nos ânimos de seus ouvintes o que nelas houvesse sido abordado. Daí a idéia das cópias, seja pela cópia manual dos alunos, seja pelo uso dos prelos!

47 Preleçóes Filosóficas, Advertência, f. 3, 1813. Grifos nossos. 
"Mas opunha-se à execução deste projeto a falta de um livro elementar, cuja liçâo fixasse e recordasse nos ânimos dos que assistissem às Preleções, as doutrinas de que nelas se houvesse tratado.

Não me restava outro recurso, senão o de pôr eu mesmo por escrito as próprias Preleçóes: e deixar tirar cópias delas aos meus ouvintes, ou fornecer-lhas por via da Impressão.

A este último expediente porém, que era sem dúvida o mais acertado encontrava a regra geral de se não deverem entregar ao Prelo, senão Obras trabalhadas com descanso, perfeitas e acabadas.

Contudo pareceu-me, que esta regra admitia algumas exceçóes, era certamente uma delas o caso em que eu me achava, absolutamente destituído de Elementos para o uso das minhas Leituras.

É pois esta urgência, e não cegueira de amor próprio, quem me move a deixar sair à luz estas Preleçóes com os numerosos defeitos, que são de esperar de obra, que deve ser composta, revista pelas competentes Autoridades, e impressa no curto espaço, que medeia entre Leitura e Leitura". ${ }^{48}$

Portanto, o filósofo nos adverte que, em meio às dificuldades de ordens diversas, superá-las significa estabelecer em uma "ciência" a indissociabilidade entre a "arte de falar" e a "arte de pensar", e que tal "ciência" estará assim conformada pelos 'elementos' que compóem o novo estatuto político do Brasil: a implementação da tipografia e a laicização da filosofia. O livro, como substrato material da reflexão filosófica, tem um alcance mais largo, pois, como 'elemento', pode forjar um 'sistema' a partir do qual as categorias que explicitam os 'objetos' e as 'palavras' legitimam o processo no qual o Brasil se civiliza. ${ }^{49}$

Agora, então, podemos perguntar: qual a função da tradução das Categorias neste contexto? Não seria mais uma vez um modo de Silvestre Pinheiro Ferreira articular a arte de pensar com a arte de falar? Não cumpriria ela a função de estabelecer os princípios que regem as condições precárias, mas legítimas, do processo denominado na 30a Preleção de "como as naçôes se civilizam e avançam em bom gosto"?

48 Preleçôes Filosóficas, Advertência, f. 3 e 4, 1813. Grifos nossos.

49 Aqui vale lembrar a definição que nos é dada de 'elemento': "qualquer das partes componentes de um Sistema”; e a tradução de Pinheiro Ferreira para $\tau \tilde{\omega} v$ őv $\tau \omega \nu \tau \hat{\alpha} \mu \dot{\varepsilon} v$

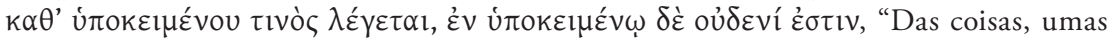
dizem-se de algum objeto; mas não estão em nenhum objeto”. Cf. Categorias, A.5. 


\subsection{As Categorias, de Aristóteles, a funçáo da traduçáo e o projeto de uma nação brasileira}

A tradução das Categorias de Aristóteles foi publicada em 1814, com folha-de-rosto e paginação próprias, embora em alguns exemplares esteja encadernada com as Preleçóes Filosóficas, em um único volume - como no caso do exemplar da Biblioteca Nacional do Rio de Janeiro, bem como do volume pertencente à Coleçáo Carolina Michaelis, do Instituto de Estudos Românicos, da Faculdade de Letras da Universidade de Coimbra. ${ }^{50}$

A folha-de-rosto já nos indica que o projeto de tradução abarca objetivos peculiares ao autor das Preleçôes, pois seu modo de traduzir está consubstanciado em uma intervençáo direta no original grego: Categorias, de Aristóteles; "traduzidas do grego e ordenadas conforme um novo plano", concebido por ele, "para uso das Preleçóes Filosóficas do mesmo tradutor".

Assim, procurando dar ao texto de Aristóteles uma feição semelhante àquela utilizada na elaboração das Preleçôes Filosóficas, isto é, o de ser um "Livro elementar", Silvestre Pinheiro Ferreira vai dividir o texto das Categorias em duas partes: uma primeira, denominada Aforismos, e a segunda, chamada de Explicaçóes, e contendo, cada uma, paginaçáo própria e progressiva; o autor justificará sua escolha na apresentação do texto da tradução em função da tese, já demonstrada nas Preleçôes Filosóficas, de que a alteração da ordem da escrita em nada altera a ordem das idéias ou a da leitura:

"Mas se não precisa de justificação a homenagem que assim tributo às Obras de Aristóteles; precisa-o tanto mais a novidade da forma, em que aparecem na presente tradução: novidade, que deve parecer à primeira vista; um total transtorno do texto do Autor. Porém este transtorno, que é na verdade grande quanto à ordem da escrita, em nada altera, nem a ordem das idéias, nem a da leitura. Porquanto se começando nós a ler o texto da Primeira Parte pela primeira palavra Equivocos (que é também a primeira do original) passarmos da palavra diferente à Explicação No 1, na Segunda Parte: e lida ela, voltarmos ao segundo $₫$ da Primeira Parte: Univocos porém etc.: e assim continuarmos, passando alternativamente do Texto às Explicaçóes, que os números, ou os asteriscos indicam: e destas ao Texto; ninguém que

50 Sobre essas ediçóes veja-se a nota 41. Vale observar ainda que a Biblioteca Nacional de Portugal possui um exemplar contendo apenas as primeiras vinte e três preleçóes. 


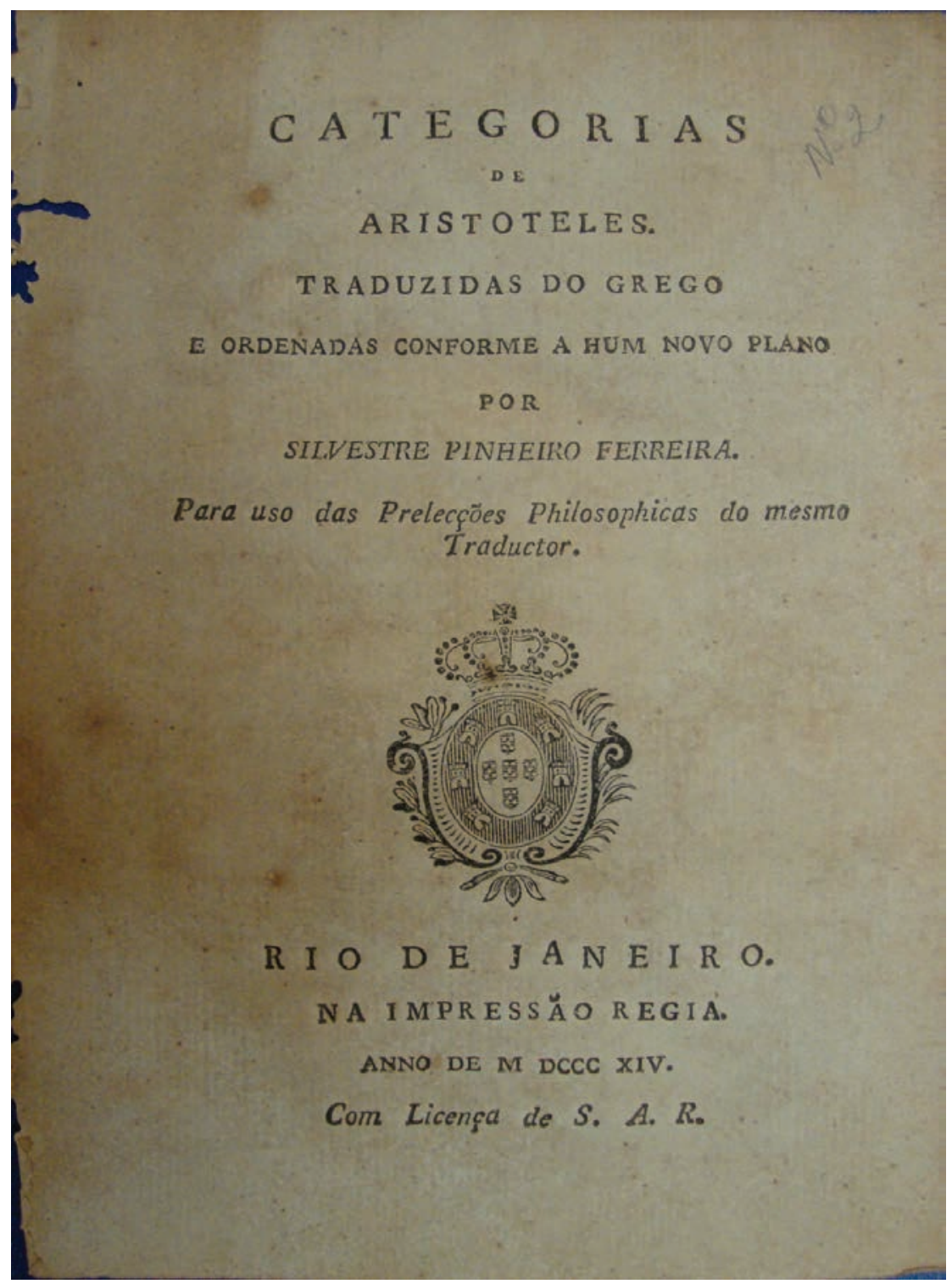

Folha-de-rosto da tradução de Silvestre Pinheiro Ferreira, diretamente do grego, das Categorias, de Aristóteles, publicada no Rio de Janeiro, pela Impressão Régia, em 1814. Trata-se da primeira publicaçáo, no Brasil, de um texto do pensamento antigo (Acervo da Fundaçáo Biblioteca Nacional, Rio de Janeiro). 
Politeía Tropical: a recepção dos clássicos, a tradição política no Brasil do século XIX e a tradução das Categorias aristotélicas por Silvestre Pinheiro Ferreira

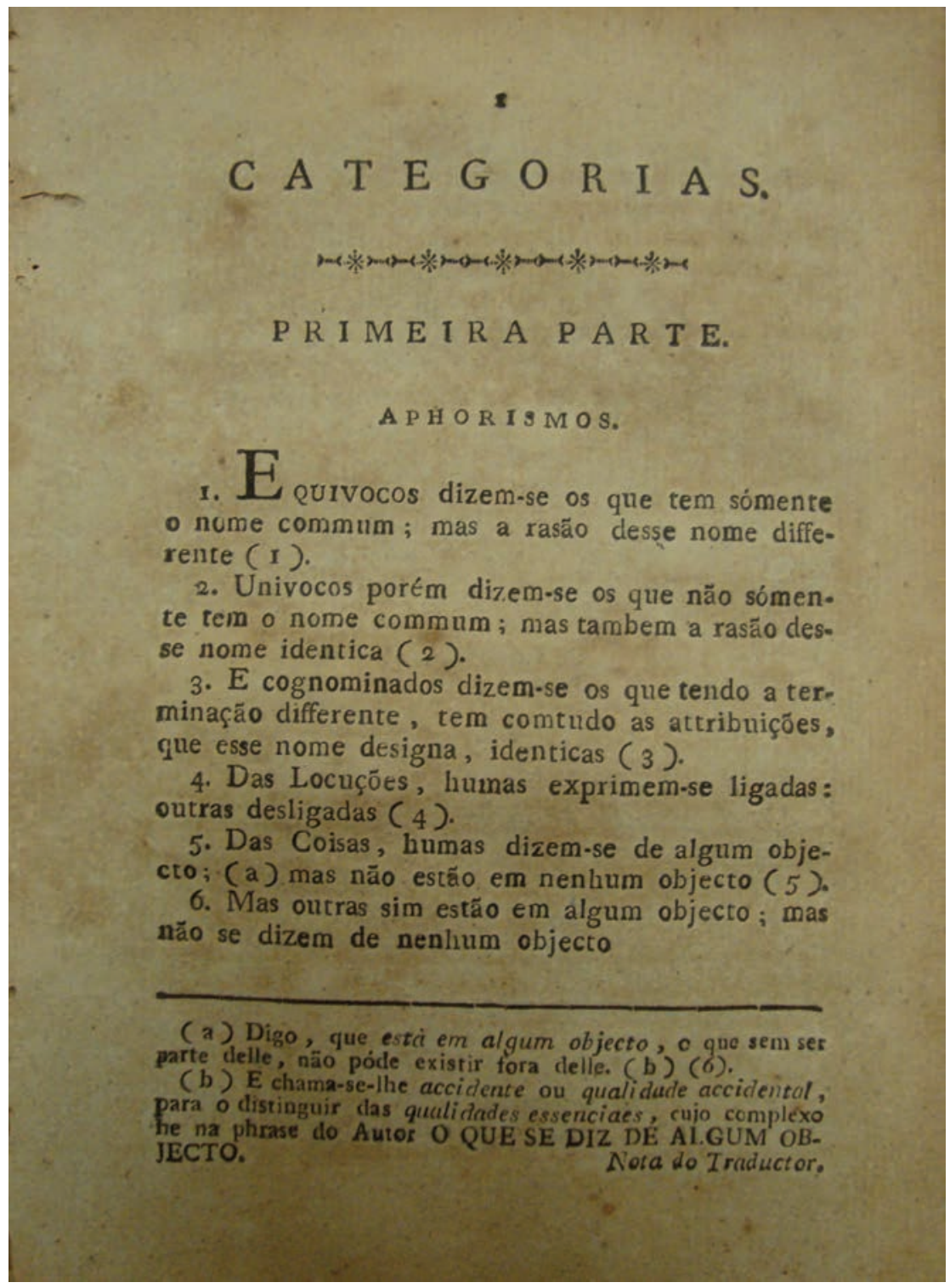

Categorias - Primeira parte chamada por Silvestre Pinheiro Ferreira de Aforismos. (Acervo da Fundação Biblioteca Nacional, Rio de Janeiro) 


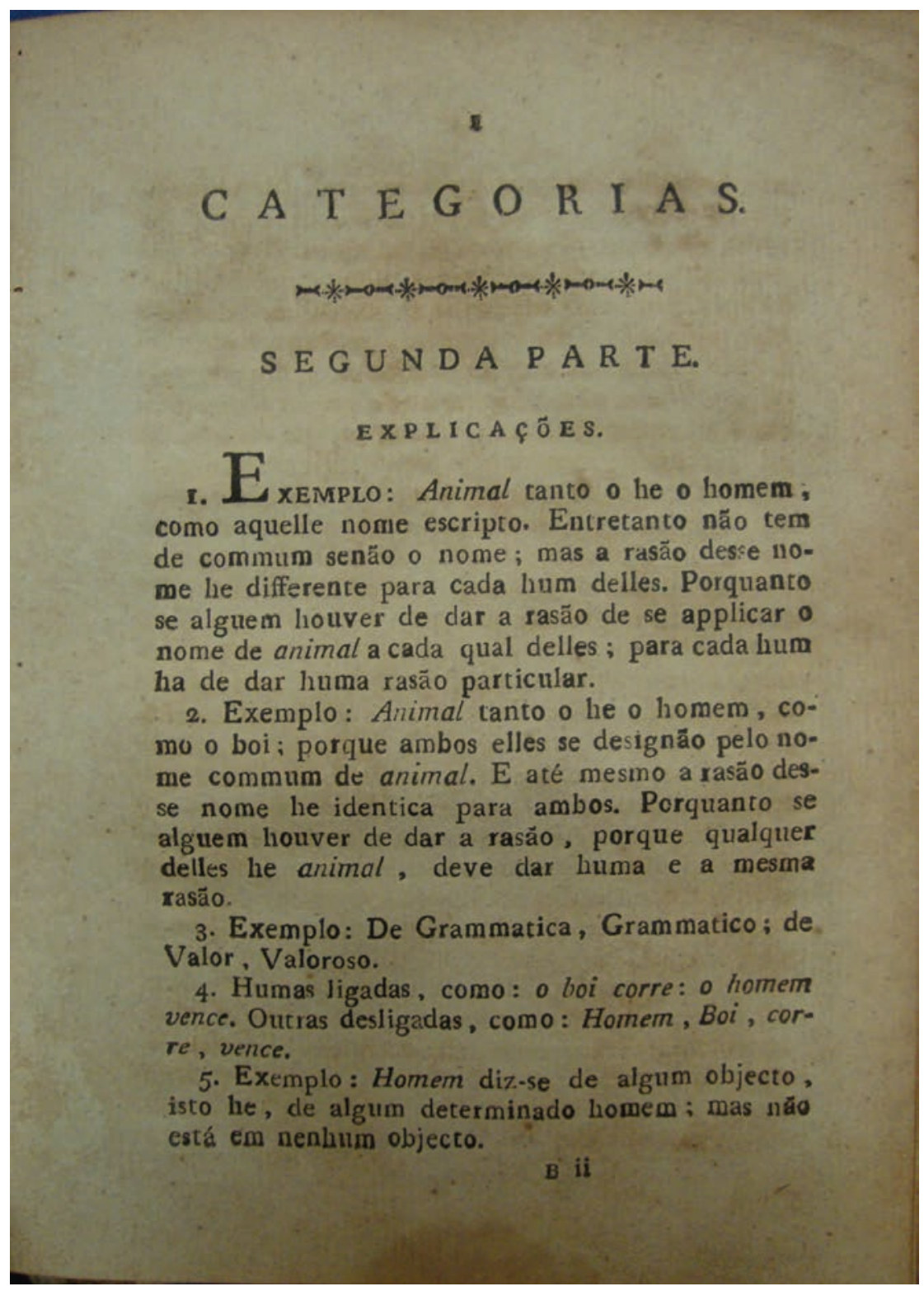

Categorias - Segunda parte chamada por Silvestre Pinheiro Ferreira de Explicaçōes. (Acervo da Fundaçấo Biblioteca Nacional, Rio de Janeiro) 
com os olhos no Original grego nos escutasse, poderia suspeitar que nele se houvesse feito a menor alteração." ${ }^{51}$

Ao dividir o texto original em Aforismos e Explicaçôes, nosso autor está atuando com a mesma "teórica das definiçôes" já utilizada nos artigos publicados em $O$ Patriota e metodicamente explicitada nas Preleçóes Filosóficas. Para tanto, parece-nos oportuno lembrar a etimologia do termo 'aforismo', do grego aphorismós, que tanto pode ser traduzido por 'definição', quanto por 'determinação', 'delimitação', e, também, como 'separação', 'distinção', portanto, a ação verbal, aphorizo, adjunta ao substantivo masculino aphorismós, consiste em definir, determinar, delimitar, separar e distinguir, sentidos que encontraremos nos textos aristotélicos - por exemplo, na Retórica, 1354a3; na Política, 1331a27; e nas próprias Categorias, 3b 20 e 3b 22; 5b 12 -, e que será traduzido por Pinheiro Ferreira em suas ocorrências nas Categorias, por 'determinaçáo..$^{2}$ Desse modo, a "novidade da forma" adotada na traduçáo parece perfeitamente consonante com as teses silvestrianas que, de certo modo, assimilam aspectos importantes de sua interpretação das Categorias.

O texto grego utilizado por Pinheiro Ferreira, como indicado ao final da "Advertência", foi o de Isaac Casaubon, editado em 1596, em Lyon, pela Oficina de Jacob Bubon, em dois volumes, in folio, contendo a Obra de Aristóteles em grego, e com a tradução para o Latim, feita por Gourchy ${ }^{53}$, e se voltássemos os nossos olhos para a tradução, como nos sugere Pinheiro Ferreira, e fizéssemos a colação do texto de grego com a tradução dividida em Aforismos e a Explicações, teríamos o quadro seguinte:

51 Ferreira 1814: f.3-4. Grifos nossos. Além da "novidade da forma” a tradução contém um modo próprio de referenciar o texto, pela numeração progressiva dos Aforismos e das Explicaçôes, em um momento em que não temos ainda a edição de Bekker, publicada em Berlim, em 1831 (Aristotelis opera, ex recensione Immanuelis Bekkeri, Ed. Academia regia Borussica, t. I, Berlin, 1831.)

52 Cf. Liddell, Scott, Jones, s.v. ’’ $\varphi$ opí $\omega$. Cf. a tradução silvestriana para os passos 3b 20: "Assim que, tanto a espécie, como o gênero, determinam as qualidades das essências;"

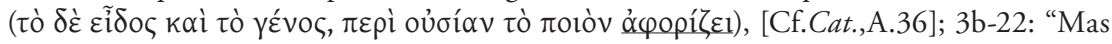

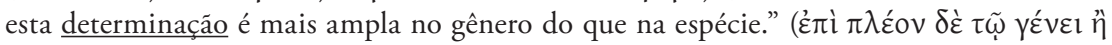

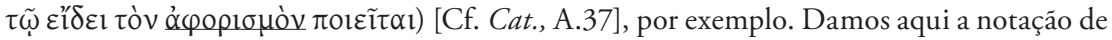
Bekker e entre colchetes a de Silvestre Pinheiro Ferreira, de tal modo que a referência fique facilmente acessível. O texto grego citado será sempre o de Isaac Casaubon.

53 Cf. Casaubon, 1590: 2 e Schmitt 1992: 92 que afirma ter Casaubon incluído em sua edição a tradução de Grouchy do Organon de Aristóteles, abandonando a tradicional versão latina de Párion. 


\section{$<$ [KАТНГОРIAI] $>$}

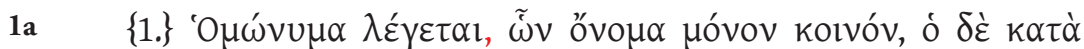

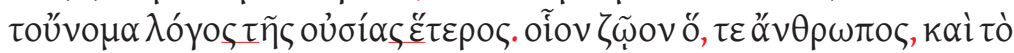

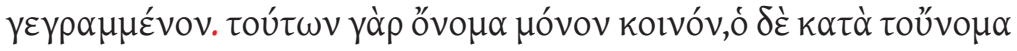

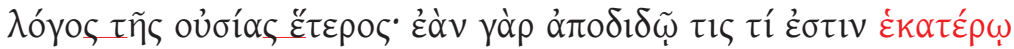

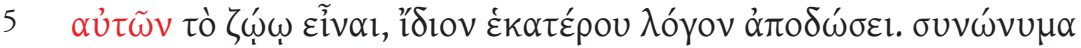

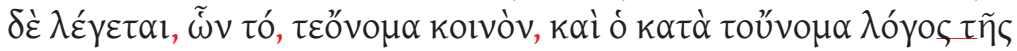

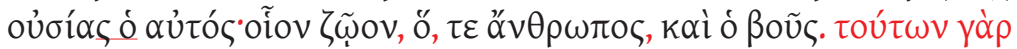

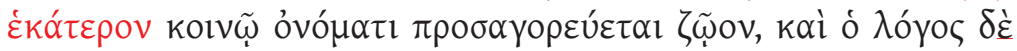

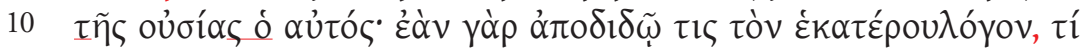

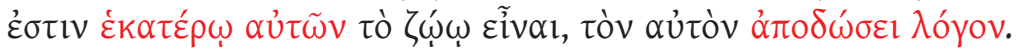

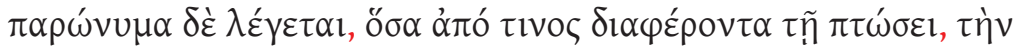

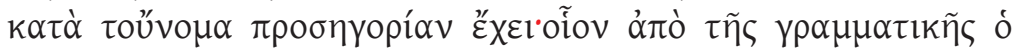

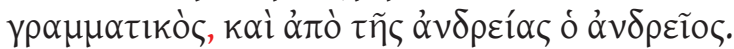

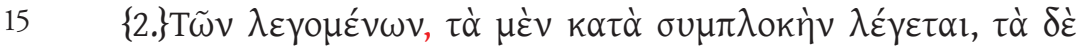

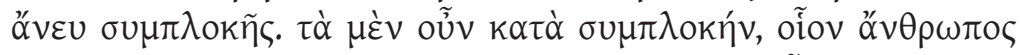

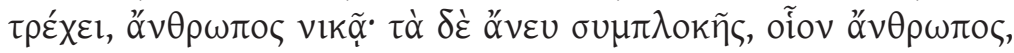
ßoũ $, \tau \rho \varepsilon ́ \chi \varepsilon l, ~ v ı \kappa \tilde{\alpha}$.

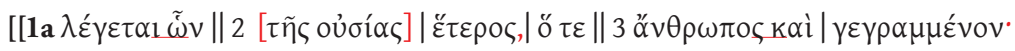

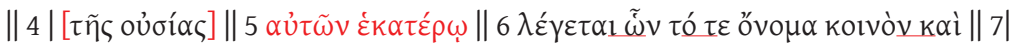

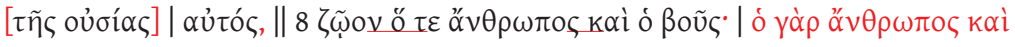

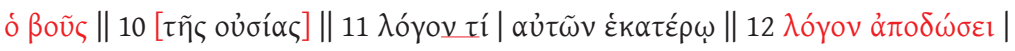

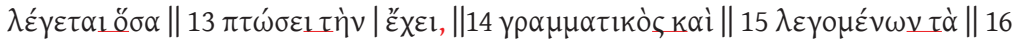

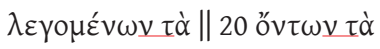




\section{CATEGORIAS ${ }^{54}$}

[AFORISMO]1. Equívocos dizem-se os que têm somente o nome comum; mas a razão desse nome diferente (1).

[EXPLICAÇÃO]1. Exemplo: Animal tanto o é o homem, como aquele nome escrito. Entretanto não tem de comum senão o nome; mas a razão desse nome é diferente para cada um deles. Porquanto se algum houver de dar a razáo de se aplicar o nome de animal a cada qual deles; para cada um há de dar uma razáo particular.

[A]2. Unívocos porém dizem-se os que não somente têm o nome comum; mas também a razão desse nome idêntica (2).

[E]2. Exemplo: Animal tanto o é o homem, como o boi: porque ambos eles se designam pelo nome comum de animal. E até mesmo a razão desse nome é idêntica para ambos. Porquanto se alguém houver de dar a razão, porque qualquer deles é animal, deve dar uma e a mesma razão.

[A]3. E cognominados dizem-se os que tendo a terminação diferente, têm contudo as atribuiçóes, que esse nome designa, idênticas (3).

[E]3. Exemplo: De Gramatica, Gramático; de Valor, Valoroso.

[A]4. Das Locuções, umas exprimem-se ligadas: outras desligadas (4).

[E]4. Umas ligadas, como: o homem corre: o homem vence. Outras desligadas, como: Homem, Boi, corre, vence.

Na seção de Aforismos o tradutor circunscreverá tudo aquilo que ele considera "elementar", e nas Explicaçôes tudo aquilo que "não acrescenta nada ao que fica dito", servindo apenas para clarificar o que foi dito:

54 No quadro acima o texto grego das Categorias é o da edição de Casaubon, com o grifo em vermelho, indicando as alteraçóes sofridas no texto em ediçóes contemporâneas, aqui colecionadas, no aparato crítico com a edição de Richard Bodéüs, publicada em 2002, por Les Belles Lettres. 
"Consiste pois esta unicamente em separar, à maneira de Notas, toda aquela parte do original, que não acrescenta nada ao que fica dito, e só serve a exemplificar, ou aclarar por qualquer outro modo, o que precede: sem que este novo arranjo violente a ligação de uma e outra coisa: nem eu tenha para isso omitido, acrescentado, ou substituído palavra alguma, do Original, pois antes as conservei na ordem da sintaxe, que cada uma delas ali ocupa. Duas são as vantagens, que me parecia, seguirem-se desta disposição: primeira, tornarem-se mais sensíveis e perceptíveis as doutrinas do Autor: Segunda, convidar mais a lerem-se, e facilitar o consultarem-se Obras, que se por algum tempo jazeram $(a)^{55}$ em uma espécie de injusto esquecimento: e por não lidas experimentaram um tanto mais injusto desprezo; isso derivou em grande parte do fastio que causava aquela multiplicidade de explicaçôes, que interrompem a dado passo o fio das idéias." ${ }^{56}$

As justificativas explicitando o plano de tradução utilizado aparecem também na "Advertência", que, tal como nas Preleçôes Filosóficas, antecede a tradução, de modo a dimensionar o contexto do trabalho filosófico.

E, se na primeira parte da "Advertência" podemos inferir um primeiro preceito do tradutor: a fidelidade ao texto original, sem acréscimos ou substituição de qualquer palavra, que devem ser conservadas em sua sintaxe original; na segunda, o valor 'formador' e 'educativo' da tradução é compreendido em dois aspectos, o da hermenêutica da obra filosófica, na medida em que as ideias de um autor podem ser mais facilmente lidas e apreendidas, e preservadas de um "injusto esquecimento". Logo, também não será difícil reencontrarmos aqui, mais uma vez explicitada, a coalescência entre a "arte de pensar" e a "arte de falar", posto que "a ordem da escrita, em nada altera, nem a ordem das idéias, nem a da leitura".

$\mathrm{Na}$ segunda parte da "Advertência" veremos que a escolha das Categorias não é apenas uma escolha filosófica, mas, também, uma escolha que, ao se demarcar como 'formadora', aponta para a tese de que a construção de

$55 \mathrm{O}$ (a) refere-se à nota acrescentada por Pinheiro Ferreira justificando o uso do pretérito do verbo jazer: "(a) Seja-me desculpado o uso deste pretérito do verbo jazer. Eu sei que os nossos bons Escritores ou se serviram de jouveram, ou o evitaram. Mas o uso geral na conversação e trato da Corte, não menos do que a analogia, são bastante autoridade em meu favor." Cf. Cat, f.4, 1814 .

56 Ferreira 1814: f.4. Grifos nossos. 
uma nação, ou melhor, a "fundação" da nação deve pautar-se também no domínio da "arte de pensar" e da "arte de falar":

\begin{abstract}
"Ninguém, que com reflexão tenha lido os Filósofos dos antigos e modernos tempos, poderá negar a Aristóteles a primazia sobre todos eles. E portanto as suas Obras deviam ser naturalmente as primeiras, que figurassem nesta como Biblioteca de Filosofia, que tenho empreendido. [...]

Quisera eu que o texto grego aparecesse em frente desta tradução: tanto para excitar a Mocidade ao estudo da Língua Grega, que no meu conceito constitui o mais glorioso monumento da perfeiçáo do Espírito humano; como também porque devendo esta tradução abundar em defeitos inevitáveis pelo pouco tempo em que sou obrigado a fazê-la e publicá-la; conviria muito, que a facilidade de a cotejarem com o texto oferecesse aos inteligentes o meio de corrigirem as faltas, que nela não pode deixar de haver em grande número, e muitas vezes de grande nota.

Por maior porém que fosse este meu desejo, não me foi possível satisfazê-lo; já porque neste nascente Estado faltam os meios para se fazer uma correta edição de um texto grego; logo que exceda a certos e muitos acanhados limites: já porque a carestia excessiva dos materiais e da mão-de-obra tornaria inútil para a maior parte das pessoas, a cujo uso este meu trabalho é dirigido, uma obra, que tendo unicamente em vista a instrução da Mocidade, deve estar ao alcance até daqueles mesmos que não gozam de avultados bens da fortuna." ${ }^{7}$
\end{abstract}

Nesse sentido, seria oportuno lembrar que as Categorias, sobre a qual pesam muitas dúvidas sobre sua autencidade, foi tida pela tradiçáo neoplatônica como um texto fundamental no processo de iniciação à filosofia e, que, juntamente com o Sobre a Interpretaçâo e os Primeiros Analiticos, formava uma tríade - com uma lógica dos termos, uma lógica das proposiçóes e uma lógica dos raciocínios - introdutória à filosofia, que Pinheiro Ferreira parece ter em conta em seu projeto de preleçôes filosóficas. ${ }^{58} \mathrm{E}$ às objeçóes feitas por Hipólito da Costa, no Correio Braziliense, que envolviam: [i] o caráter

57 Ferreira 1814: f. 1-5. Grifos nossos.

58 Sobre a questão da autencidade das Categorias, veja-se, por exemplo, Brunschwig, J. Les Catégories. DPhA, I, 1994: 109-124; Bodéüs 1995: 141-154; Dumoulin 1980: 23-32; Ross 1939: 427-433, e Rutten 1985: 315-336. 
'elementar' das Preleçóes Filosóficas - não um curso elementar de filosofia, como havia suposto o correspondente do Correio Braziliense -, tanto no que diz respeito à "instrução da mocidade" (náo para toda a mocidade, mas para aquela que já tenha um curso de estudos que lhe dê os princípios e o entendimento da linguagem das ciências), quanto ao fato delas trazerem à tona "os princípios elementares da Filosofia"; [ii] a "abundância de definições", que, ao contrário do que pensa Hipólito da Costa, constituem-se em um modo de apreensão da "verdade" que, como parte da "Arte de ensinar", compôe-se em "um tesouro", cujas chaves "são as definiçôes"; [iii] a definição da palavra 'definiçãa', e, [iv] a crítica feita aos comentários ao texto das Categorias e ao fato de o autor ignorar que elas foram falsamente atribuídas a Aristóteles:

[...] "as observaçôes que da IX Preleção por diante se encontram sobre as Obras d'Aristóteles com qualquer dos inumeráveis Comentadores daquele Filósofo; e mostre de qual deles extraídas. E já que falamos d'Aristóteles, de quem o mesmo Crítico diz que eu deveria saber que as Categorias lhe foram falsamente atribuídas; respondo: que sendo para o meu intento questáo muito ociosa, como se chamava o Autor daquela Obra, pois que isso nada tira nem acrescenta ao seu merecimento; me não devo demorar em mostrar que ela é com efeito de Aristóteles; e limito-me a remeter o nosso Crítico para a Prefação que o célebre Buhle fez preceder às mesmas Categorias na edição que deu das Obras d'Aristóteles em Duas Pontes no ano 1791, e seguintes."59,

Pinheiro Ferreira irá respondê-las na $18^{a}$ Preleção e no Suplemento ao Índice das vinte e duas primeiras preleções.

Portanto, a opção pela tradução do texto grego, o lamento pela impossibilidade de uma edição bilingue, grego-português, cumpre, também, conforme sublinha nosso autor, a função 'formadora' - tanto no que diz respeito ao exercício da filosofia, quanto ao da cidadania -, que pretende, pela "instruçáo da mocidade", garantir, como já sublinhara em O Patriota, a "contemporaneidade dos séculos". ${ }^{60}$ Sob essa ótica, o filósofo e o tradutor não estão dissociados, e a possibilidade de traduzir parece ser uma exigên-

59 Cf. Preleçôes Filosóficas, \$583-588, e Suplemento 1813: 99-100.

60 Veja-se o item 1.1, p. 7-8; 16-21. Para a importância filosófica do conhecimento das línguas, cf. Preleçöes Filosóficas, \$949-952. 
cia, uma condição natural, da reflexão filosófica, sobretudo em um "nascente Estado" como o Brasil, nas primeiras décadas do século XIX.

Assim, o processo em que as naçóes "se civilizam", ${ }^{61}$ a "construção do Bom Gosto" "62, supóe, para o nosso filósofo, não somente a coalescência entre a "Arte de Pensar" e a "Arte de Falar", mas, também, a 'Arte de Traduzir' como substrato da comunidade política, da conformação do Estado no alicerce secular da contemporaneidade das ideias, que poderá ser confirmada em toda a reflexão silvestriana acerca da monarquia como forma constitucional, esboçada nas Memórias politicas sobre os abusos gerais e os modos de os reformar e prevenir a revolução no Brasil, redigidas por ordem do Príncipe Regente, em 1814/1815, nas Cartas sobre a Revoluçáo do Brasil, e, posteriormente, nas Observaçôes sobre a Constituição do Império do Brasil e sobre a Carta Constitucional do Reino de Portugal, e no Manual do Cidadão em um Governo Representativo, publicado, em aparente forma 'dialogal', pois constituído de perguntas e respostas, sem, entretanto, a determinação de personagens, em 1834.

Ao revigorar as Categorias aristotélicas em "Aforismos" e "Explicaçôes", Pinheiro Ferreira estava, certamente, redefinindo no "Novo Mundo" a antiga concepção grega de 'politeía' e subscrevendo o estatuto da vida política - dos direitos e deveres dos cidadáos e do Estado - na "contemporaneidade dos séculos", prescrita em "O Patriota" e revisitada no aparato filosófico das Preleçôes, e tão bem explicitada na paráfrase do primeiro Aforismo do Corpus

61 Que o Brasil estivesse no horizonte silvestriano, o parecer escrito por ele, em março de 1822, sobre a situação do Brasil, parece ratificar: "O Brasil desde seu descobrimento tem sido sempre governado colonialmente, quer dizer, por medidas e providências que os governadores de cada capitania julgavam ser ditadas pelas circunstâncias. Esta é a única forma de governo praticável em uma sociedade nascente. Mas S. M., depois de ter estado alguns anos no Brasil, convenceu-se de que as principais povoaçóes dele estavam já chegadas àquele grau de civilização em que as sociedades deixam de ser governadas por ditadores para o serem por magistrados sujeitos a uma marcha regular e conforme a um sistema de leis uniformes em toda a extensão da monarquia. Foi nesta mente pois que S. M. declarou o Brasil elevado à categoria de reino." (Ferreira, 1822, f.2, Manuscrito I - 31, 22, 009, FBN).

62 A importância 'filosófica das línguas', a função gnosiológica da 'gramática filosófica' expostas em $O$ Patriota e fundamentadas nos comentários ao texto de Aristóteles nas Preleçôes Filosóficas, no $\$ 941$, remete específicamente para a "formação do Gosto”: "E se é indispensável a todo o homem que quer formar o Gosto sobre os diferentes gêneros de Poesia ler o Ariosto, o Tasso, Corneille, Racine, Lafontaine, Shakespeare, Milton, Klopstock, etc, nos seus originais; como poderá suprir o que só em Homero, em Sófocles, em Demóstenes, em Horácio, em Terêncio, em Cícero, se pode encontrar, nem se pode traduzir em nenhuma outra Língua?” 
Hippocraticum feita por Pedro Nava, em 1948, citada na epígrafe deste texto: se "os fatos são passageiros", se "as datas incertas" e se "os homens são mortais, - só as ideias sáo permanentes e eternas as categorias por que elas se exprimem." 
Politeía Tropical: a recepção dos clássicos, a tradição política no Brasil do século XIX e a tradução das Categorias aristotélicas por Silvestre Pinheiro Ferreira

\section{Referências Bibliográficas}

\section{Obras de Silvestre Pinheiro Ferreira}

\section{Manuscritos}

Ferreira, S. P. (1814), Proposta sobre o regresso da corte para Portugal e providências convenientes para prevenir a revolução, e tomar a iniciativa na reforma politica, 22 de abril. 3f. (FBN, Seção de Manuscritos, I-31,21,010.)

Ferreira, S. P. (1822), Memórias e cartas biográficas versando sobre os fatos políticos sobrevindos no Rio de Janeiro à revolução constitucionalista do Porto e Lisboa, desde suas repercussóes e consequentes sublevaçôes de fevereiro e abril de 1821 até o regresso de D. João VI com a corte para Portugal. Seção de Manuscritos da FBN, I-31, 21, 009.

Ferreira, S. P. (1821), Carta de Silvestre Pinheiro Ferreira escrita a bordo da nau D. João a 26 de maio de 1821, dirigida ao rei D. João VI, pedindo instruçōes para organizar a casa e serviço de El-rei em Lisboa. Seção de Manuscritos, FBN, II, 30, 34,9-No 1..

\subsection{Impressos}

Ferreira, S. P. (1813), Preleçōes Filosóficas. Rio de Janeiro: Impressão Régia.

Ferreira, S. P. (1970), Preleçóes Filosóficas. Introdução de Antonio Paim. 2 ed. São Paulo: Edusp, Editorial Grijalbo.

Ferreira, S. P. (1996), Preleções Filosóficas. Introdução de José Esteves Pereira. Lisboa: Imprensa Nacional.

Ferreira, S. P. (1814), Aristóteles. Categorias. Tradução e notas por Silvestre Pinheiro Ferreira. Rio de Janeiro: Impressão Régia.

Ferreira, S. P. (1884), "Memórias políticas sobre os abusos gerais e modos de os reformar e prevenir a Revolução Popular, redigidas por ordem do Príncipe Regente - 1814/1815”, Instituto Histórico e Geográfico Brasileiro 47: 1-13. [a1814]

Ferreira, S. P. (1826), Essai sur la psychologie, comprenant la théorie du raisonnement et du langage, l'ontologie, l'esthétique et la dicósyne. Paris: Rey et Gravier; J. P. Allaud.

Ferreira, S. P. (1831), Observaçóes sobre a carta constitucional do Reino de Portugal e a constituição do Império do Brasil. Paris: Of. Typ. De Casimir.

Ferreira, S. P. (1834), Manual do cidadão em um Governo Representativo, ou princípios de direito constitucional administrativo e das gentes. Paris: Rey e Gravier. [3v.] 
Ferreira, S. P. (1835), Observaçôes sobre a constituiçāo do Império do Brazil e sobre a Carta Constitucional do Reino de Portugal. $2^{\text {a }}$. ed. aumentada com as observaçôes do mesmo autor sobre a lei das reformas do Império do Brazil. Paris: Rey e Gravier; J. P. Aillaud.

Ferreira, S. P. (1837), Breves observaçōes sobre a constituição política da monarquia portuguesa: decretada pelas Cortes Gerais extraordinárias e constituintes ... . Paris: Rey et Gravier.

Ferreira, S. P. (1839), Noçôes Elementares de Philosophia e suas aplicaçôes às sciências morais e politicas. Paris: Rey et Gravier.

Ferreira, S. P. (1841), Precis d’un cours de philosophie élémentaire: ontologie, psychologie, idéologie. Paris: Eduard Garnot.

Ferreira, S. P. (1843), "Divisão do império do Brasil em cinco monarquias confederadas - Sr. D. Pedro 2o chefe da Confederação”, Diário do Rio de Janeiro, 22 nov.: 1.

Ferreira, S. P. (1887), "Cartas sobre a revolução no Brasil, editadas por F. Ramiz Galvão”, Anais da Biblioteca Biblioteca Nacional. [v. 2 e 3]

Ferreira, S. P. (1888), "Cartas sobre a revolução do Brasil", Instituto Histórico e Geográfico Brasileiro 51. 1: 239-377.

Ferreira, S. P. (1960), "Silvestre Pinheiro Ferreira: Escritos Filosóficos”, Revista da Universidade de Coimbra 19: 29-319.

Ferreira, S.P. (1976), Ideias Políticas. Rio de Janeiro: PUC-Rio; Editora Documentário. [Coletânea de textos].

\subsection{Outras fontes consultadas}

Bacelar, B. L. M. (1783), Gramática filosófica e ortográfica racional da língua portuguesa. Lisboa: Na Officina de Simão Thaddêo Ferreira.

Barbosa, J. S. (1822), Gramática filosófica da lingua portuguesa, ou princípios da Gramática geral aplicados à nossa linguagem. Lisboa: Tipografia da Academia das Ciências.

Couto e Melo, J. C. (1818), Gramática filosófica da linguagem portuguesa. Lisboa: Impressão Régia.

Centro de Documentação do Pensamento Brasileiro (1982), Silvestre Pinheiro Ferreira (17691846): Bibliografia e estudos. Salvador: CDPB.

Garat, D.-J. (1783), "Lettres sur Bayonne et les Basques”, Mercure de France 8: 63-73.

Marrocos, L. J. dos S. (1934), "Cartas de Luiz Joaquim dos Santos Marrocos, escritas à sua família no Rio de Janeiro, de 1811 a 1821”, in Anais da Biblioteca Nacional do Rio de Janeiro. Rio de Janeiro, Serviço Gráfico do Ministério da Educação.

(1849), Novo Catálogo das Obras do Publicista Português Silvestre Pinheiro Ferreira que existem à venda em Lisboa .... Lisboa: Typ. J. B. Morando, 24 p.

(1813-1814) O Patriota, Jornal Literário, Político, Mercantil. Rio de Janeiro: Impressão Régia. 
Politeía Tropical: a recepção dos clássicos, a tradição política no Brasil do século XIX e a tradução das Categorias aristotélicas por Silvestre Pinheiro Ferreira

Silva, I. F. da (1862), Silvestre Pinheiro Ferreira, in Dicionário Bibliográfico Português. Lisboa, t. 7: 259-273.

Verney, L. A. (1746), Verdadeiro Método de Estudar para ser útil à República e à Igreja: proporcionado ao estilo e necessidade de Portugal exposto em várias cartas escritas pelo R.P. ${ }^{* * * B a r b a d i n h o ~ d a ~ C o n g r e g a c ̧ a ̃ o ~ d e ~ I t a ́ l i a ~ a o ~}{ }^{* * *}$ R. R.P. Doutor da Universidade de Coimbra. Valença: Oficina de Antonio Balle. [2 v.]

Zaidman, D. (1977-1978), “O Patriota, jornal literário, político e mercantil, 1813-1814. Índice”, in Rodrigues, J. H. (Coord.), Coleção Mattoso Maia de Instrumentos para Pesquisa em História do Brasil. Niterói: UFF.

\section{Aristóteles: Ediçôes e Comentários}

\subsection{Edições das Categorias}

Bekker, I. (1831), Aristotelis opera, ex recensione Immanuelis Bekkeri. Berlin: Academia regia Borussica. [Editio altera qvam cvravit Olof Gigon, Berlin, 1960], p. 1-15, t. 1.

Bodéüs, R. (2002), Aristote. Catégories. Texte établi et traduit par R. Bodéüs. Paris: Les Belles Lettres.

Casaubon, I. (1590), Aristotelis stagiritae philosophorvm Omnivn longe principis. Lyon: Guillelmun Laemarium.

Colli, G. (1955), Organon. Introduzione, traduzione e note di Giorgio Colli. Turin: Einaudi.

Paluello, M. (1949), Aristotelis Categoriae et liber De interpretatione, recognovit brevique adnotatione critica instruxit. Oxford: Oxford University Press. [reimp. 1949, OCT].

\subsection{Estudos e Comentários às Categorias e História do Texto.}

Bodéüs, R. (1995), "Sur l'unité stylistique du texte des Catégories d'Aristote", in Motte, A. e Denooz, J. (eds.), Aristotelica Secunda: Mélanges offerts à Cristian Rutten. Liège: C.I.P.L.: 141-154.

Dumoulin, B. (1980), “Sur l'authenticité des Catégories”, in Aubenque, P. (éd.), Concepts et catégories dans la pensée antique. Paris: Vrin: 23-32.

Düring, I. (1990), Aristóteles. Traducción y edición de Bernabé Navarro. México: UNAM.

Rutten, Chr. (1985), Stylométrie des Catégories. Aristotelica: Mélanges offers à M. De Corte. Bruxelles-Liège, Ousía: 315-336.

Schmitt, C. (1992), Aristote et la Renaissance. Traduit de l'anglais et présenté par Luce Giard. Paris: PUF. 


\section{Estudos e Comentários}

Alcides, S. (2007), "O lado B do neoclassicismo luso-brasileiro: patriotismo e poesia no 'poderoso império'", in Kury, L. (Org.), Iluminismo e império no Brasil: O Patriota (1813-1814). Rio de Janeiro: Fiocruz: 103-140.

Bordes, J. (1982), Politeía dans la pensée grecque jusqu’à Aristote. Paris: Les Belles Lettres.

Candido, A. (1976), Literatura e sociedade: estudos de teoria e história literária. 5ª . ed. revista. São Paulo: Editora Nacional.

Canfora, L. (2002), Convertire Casaubon. Milano: Adelphi.

Canfora, L., Corcella, A. (1992), "La letteratura política e la sttoriografia”, in La produzione e la circolazione del testo. Volume 1: la pólis. Roma: 433-471.

Carvalho, L. R. (1978), As reformas pombalinas da Instrução Pública. São Paulo: Edusp.

Cataldi, S. (2004), Poleis e Politeiai: experienze politiche, tradizioni letterarie, progetti constituzionale. Atti del Convegno Internazionale di Storia Greca. Alessandria: Edizioni dell'Orso.

Costa, J. C. (1956), Contribuição à história das idéias no Brasil. Rio de Janeiro: José Olympio.

Couto, M. A. (2004), "Gramática e a teorização linguística em Portugal: a Gramática Filosófica de João Soares Barbosa”, Revista Galega de Filoloxía 5: 11-31

Coxito, A. (2006), Estudos sobre a filosofia em Portugal na época do Iluminismo. Lisboa: Imprensa Nacional-Casa da Moeda.

Cruz, I. (2001), "Silvestre Pinheiro Ferreira: o viajante sombra", Atalaial Intermundos. Revista do Centro Interdisciplinar de Ciência, Tecnologia e Sociedade da Universidade de Lisboa 8/9: 308-330, 2001. (disponível também em http://www.triplov.com)

Ehrenberg, V. (1980), Lo stato dei greci. Traduzione de Ervino Pocar. Firenze: La Nuova Itália.

Ferreira, T. M. T. B. da C. (2007), "Redatores, livros e leitores em O Patriota", in Kury, L. (Org.), Iluminismo e império no Brasil: O Patriota (1813-1814). Rio de Janeiro: Fiocruz: 41-66.

Gonçalves, M. F. (2006), "Iluminismo e pensamento linguístico em Portugal: o exemplo das gramáticas filosóficas", Actas do VI Congrès de Linguistica General. Barcelona, 18-21 de abril de Universitat de Barcelona. [Gonçalves, Maria Filomenta. Maria https://www. academia.edu/6410929/Iluminismo_e_pensamento_linguistico_em_Portugal_o exemplo_das_gramaticas_filosoficas]

Guimarães, M. L. S. (2007), “As luzes para o Império: história e progresso” in Kury, L. (Org.), Iluminismo e império no Brasil: O Patriota (1813-1814). Rio de Janeiro: Fiocruz: 67-102.

Houaiss, A. (2001), Dicionário Houaiss da língua portuguesa. Rio de Janeiro: Objetiva. 
Politeía Tropical: a recepção dos clássicos, a tradição política no Brasil do século XIX e a tradução das Categorias aristotélicas por Silvestre Pinheiro Ferreira

Kristeller, P. (1995), Tradição clássica e pensamento do Renascimento. Tradução de Artur Mourão. Lisboa: Edições 70.

Kury, L. (2007), “Descrever a patria, difundir o saber”, in Kury, L. (Org.), Iluminismo e império no Brasil: O Patriota (1813-1814). Rio de Janeiro: Fiocruz: 141-178.

Lidell, H. J., Scott, R. e J. (1983), A Greek-English Lexicon. Oxford: Oxford University Press.

Lima, M. de. O. (2006), D.João VI no Brasil. 4.ed. Rio de Janeiro: Topbooks.-Lyra, M. de L. V. (1994), A utopia do poderoso império. Portugal e Brasil: bastidores da política, 17981822. Rio de Janeiro: Sette Letras.

Manchester, A. K. (1970), "A transferência da Corte Portuguesa para o Rio de Janeiro", in Keith, H., Edwards, S. F. (eds.), Conflito e continuidade na sociedade brasileira. Tradução de Laurêncio de Melo. Rio de Janeiro: Civilização Brasileira: 177-217.

Manville, P. B. (1990), The origins of citizenship in ancient Athens. Princeton: Princeton University Press.

Moraes Augusto, M. G. de. (2010), "A tradição da retórica clássica no Brasil: entre a filosofia e a poesia”, in Assunção, T. R., Flores-Jr, O., Santos, M. M. (eds.), Ensaios de retórica antiga. Belo Horizonte: Tessitura: 313-350.

Moraes Augusto, M. G. de (2012/2013), “Politeía e utopia: o caso platônico”, Kléos, Pragma/ UFRJ 16-17: 128-135.

Moraes, R. B. de. (1969), Bibliografia brasileira do periodo colonial: Catálogo comentado das obras dos autores nascidos no Brasil e publicadas antes de 1808. São Paulo: Instituto de Estudos Brasileiros da Universidade de São Paulo.

Moraes, R. B. de (2006), Livros e bibliotecas no Brasil colonial. 2.ed. Brasília: Briquet de Lemos Livros.

Morel, M. (2007), "Pátrias polissêmicas: República das Letras e imprensa na crise do império português na América, in Kury, L. (Org.), Iluminismo e império no Brasil: O Patriota (1813-1814). Rio de Janeiro: Fiocruz: 15-40.

Nascentes, A. (1967), Dicionário da Lingua Portuguesa. Rio de Janeiro: Academia Brasileira de Letras, Imprensa Nacional. $4 \mathrm{v}$.

Paim, A. (1974), História das idéias filosóficas no Brasil. 2 ed. São Paulo: Grijalbo, Edusp.

Paim, A. (1974), "Introdução", in Ferreira, Silvestre Pinheiro. Preleçōes Filosóficas. 2 ed. São Paulo: Edusp, Editorial Grijalbo: 7-12.

Pattison, M. (1892), Isaac Casaubon - 1559-1614. Oxford: Clarendon Press.

Praça, J. J. Lopes (1974), História da filosofia em Portugal. Lisboa: Guimarães.

Rizzini, C. de A. (1988), O livro, o jornal e a tipografia no Brasil: (1500-1822). São Paulo: Imprensa Oficial do Estado de São Paulo, Imesp. (Ed. Fac-similar). 
Saraiva, A. J. (1996), Por uma história da cultura em Portugal: Renascimento e Contra Reforma. 2.ed. Lisboa: Gradiva. v. 2.

Sérgio, A. (1934), Ensaios. Lisboa: Seara Nova.

Silva, M. B. N. (1975), Silvestre Pinheiro Ferreira: ideologia e teoria. Lisboa: Sá da Costa.

Silva, M. B. N. (1978), Cultura e sociedade no Rio de Janeiro:1808-1821. 2.ed. São Paulo: Ed. Nacional. (Brasiliana, v. 363)

Silva, M. B. N. (2005), Ser nobre na Colônia. São Paulo: Unesp.

Sucupira, N. (1976), "O Seminário de Olinda e outros seminários”, in Diegues Júnior, M. (Org.). História da Cultura Brasileira. Rio de Janeiro: MEC/FENAME/CFC: 356373.

\section{Nota final}

Esta pesquisa vem sendo desenvolvida com o apoio do PNAP/2013, da Fundação Biblioteca Nacional do Rio de Janeiro, a quem agradecemos. Gostaríamos, também, de sublinhar agradecimentos especiais às bibliotecárias da FBN, Vera Lúcia Faillace, chefe da Seção de Manuscritos, à Profa. Ana Virgínia Pinheiro, chefe da Seção de Obras Raras, pela atenção e pela generosidade com que sempre me têm auxiliado nas muitas dificuldades encontradas, como sabemos, no dia-a-dia de uma pesquisa, e ao mestrando Luan Roborêdo Lemos, pelas afinidades na leitura das Categorias. 
Maria de Fátima Sousa e Silva é Professora Catedrática do Instituto de Estudos Clássicos da Universidade de Coimbra. Desenvolveu, como tese de doutoramento, um estudo sobre a Comédia Grega Antiga (Crítica do teatro na Comédia Grega Antiga), e, desde então, tem prosseguido com investigação nessa área. Publicou já traduções comentadas de nove comédias de Aristófanes, além de um volume com a tradução das peças e dos fragmentos mais significativos de Menandro.

Maria das Graças de Moraes Augusto é Professora Titular no Departamento de Filosofia do Instituto de Filosofia e de Ciências Sociais da Universidade Federal do Rio de Janeiro (UFRJ). A sua investigação sobre História da Filosofia Antiga abrange temas como Platão e a herança platónica, filosofia e conhecimento no pensamento antigo, filosofia e literatura na tradição antiga e recepção dos clássicos gregos no Brasil.

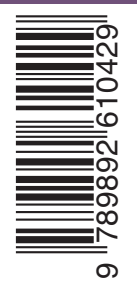


OBRA PUBLICADA

COM A COORDENAÇĀO

CIENTÍFICA
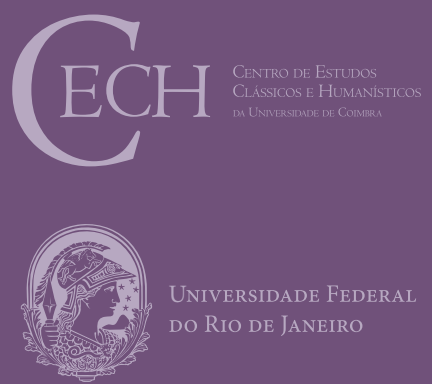

- U 